\title{
The Exception-Based Model
}

The timing of the emergence of the 'environment issue', vis-à-vis international cooperation on economic matters, contributed greatly to shaping the relationship between the international environmental and trade regimes. However, the chronological unfolding of these events does not, in itself, explain the environment being forced in a corner of the international trade regime and being treated merely as an 'exception'. It is not simply a matter of when these regimes emerged, but also of how they were perceived by their respective founders. By the time environmental protection emerged as an international concern in the 1970s, trade policy had become the province of a technocracy, a trade policy elite, embodied by the Secretariat of the General Agreement on Tariffs and Trade (GATT) - although including a much larger community of trade experts - which was insulated from all other areas of international cooperation. ${ }^{1}$ After the GATT founders, moved largely by political interests, had made sure that the Agreement would contain exception clauses-such as Article $\mathrm{xx}$ - to provide countries with the necessary space to pursue domestic policy goals, the trade policy elite recast 'embedded liberalism' as 'economics', and "economics became ideology, the ideology of free trade." From this perspective, government intervention, even when it pursued legitimate policy goals, was regarded with suspicion as potential protectionism in disguise.

Soon, the trading system came to be seen as being "for free trade and free markets, and against governmental interference,"3 as opposed to environmental protection, which could not be realized through trade liberalization and market mechanisms alone but required governmental intervention instead. As a result, the relationship between trade and the environment started being framed in terms of conflicts.

As the international trade system was considerably more mature than any part of international environmental law, and had continued to develop largely divorced from environmental considerations, it should be no surprise that, as soon as the first conflicts between economic and environmental

1 Robert Howse, 'From Politics to Technocracy—And Back Again: The Fate of the Multilateral Trading Regime' (2002) 96 American Journal of International Law 94, 98.

2 Ibid., 99.

3 Andrew Lang, World Trade Law After Neoliberalism. Re-Imagining the Global Economic Order (Oxford University Press, 2013), p. 4. 
values emerged, the approach adopted to address them was strongly tradecentered: trade rules became the frame of reference and environmental measures the 'object' to be evaluated, rather than the other way around.

\section{The Environment Cornered in Exception Clauses}

It is not surprising that the environment/trade debate is focused on how environmental issues can be squared with the one internationally accepted legal framework that does exist— the GATT. ${ }^{4}$

EDITH BROWN WEISS, 1992

During the first years of coexistence of the two regimes, the interface between their respective goals - economic growth and environmental protection - was framed in terms of conflict. When these conflicts first emerged, trade norms and institutions had already been in place for several decades and had developed into a full-fledged legal regime. On the contrary, environmental norms and institutions were still highly fragmented, lacking a focal point comparable to the GATT, or a dedicated dispute settlement mechanism similar to the one available under first the GATT, and then under the World Trade Organization (WTO).

It should be no surprise then, borrowing Edith Brown-Weiss' words, that when the tensions between trade and environmental objectives suddenly emerged at the dawn of the 1990s, they were framed from a trade law - rather than an environmental law-perspective. How could one "simply dismiss the obligations of the GATT where they conflict with environmental values [when] over 100 countries are party to the GATT and ... it is one of the most highlydeveloped international regimes"? 5 Indeed, it seems that one simply could not.

Soon, trade rules became the framework of reference and environmental measure the 'object' to be evaluated, rather than the other way around. ${ }^{6}$ Just

4 Edith Brown Weiss, 'Environment and Trade as Partners in Sustainable Development: A Commentary' (1992) 86 American Journal of International Law 728, 729.

5 Ted L. McDorman, 'The 1991 U.S.-Mexico GATT Panel Report on Tuna and Dolphin: Implications for Trade and Environment Conflicts' (1992) 17 North Carolina Journal of International Law \& Commercial Regulation 461, 479.

6 More often than not, the conflict occurs between an international trade norm (i.e. of the GATT or a free trade agreement) and a domestic environmental law or policy (legitimacy conflict). It is rare that the conflict materializes between two international norms (a trade and an environmental norm, which would constitute a normative conflict). Most environmental treaties do not require state-parties to adopt measures that are inconsistent with the GATT, but rather they usually set out a goal or a target, leaving the parties free to decide the measures to adopt to fulfill it. The fact that most trade/environment conflicts are legitimacy 
like by wearing glasses with red lenses everything around us suddenly becomes red - the pale colors become pink and the dark colors crimson-using trade law as the framework or 'lens' through which environmental measures are evaluated leads to a somehow distorted vision of such measures, which end up being translated in economic jargon and assessed for their economic importance and impact on trade flows, rather than for their inherent environmental or social values: lax environmental laws were immediately labelled as implicit subsidies, and measures that restricted trade in highly polluting - or otherwise environmentally harmful — products were simply referred to as non-tariff barriers. ${ }^{7}$ Indeed, while each and every form of governmental action has an impact on trade, identifying certain actions as 'barriers to trade' requires a certain shared understanding of what constitutes an acceptable form of government intervention and what does not. ${ }^{8}$ This 'shared understanding', just like the language that prevailed to describe environmental measures and the parameters used to assess their trade restrictiveness, were those spoken and developed by the trade community, and largely reflected the neoliberal economic thought which provided their shared narrative.

And it was precisely this 'shared understanding' that ensured, once the first questions on the relationship between trade and the environment arose, that the latter would be 'cornered' in exception clauses. In fact, as this chapter will show, these clauses had not been drafted with the environment in mind, and if they soon became the only place where environmentalists could find refuge, it was because of the debate being approached from a free-trade perspective and neoliberalism being the dominant shared narrative.

\subsection{The Environment Seen through Free Trade Glasses}

In his preparation for the Stockholm Conference, Maurice Strong had asked the GATT Secretariat to prepare a document on the link between trade and the environment. The outcome was a study entitled Industrial Pollution Control and

conflicts can explain, at least in part, why they are addressed using trade law as the framework of reference.

7 Jeffrey L. Dunoff, 'Rethinking International Trade' (1998) 19(2) University of Pennsylvania Journal of International Economic Law 347, 355.

8 See John W. Evans, The Kennedy Round in American Trade Policy: The Twilight of the GATT? (Harvard University Press, 1971); Daniel K. Tarullo, 'Logic, Myth and the International Economic Order' (1985) 26 Harvard International Law Journal 553, and 'Beyond Normalcy in the Regulation of International Trade' (1987) 10o Harvard Law Review 546; Judith Goldstein, Ideas, Interests, and American Trade Policy (Cornell University Press, 1993); Howse, 'From Politics to Technocracy' (n 1) 94; and Lang, World Trade Law After Neoliberalism (n 3) 170. 
International Trade, ${ }^{9}$ which marked the first step taken by the trade community in the unexplored territory of environmental protection. In this endeavor, the Secretariat surveyed a number of issues that national anti-pollution measures might raise for international trade law, having specific regard to the provisions and objectives of the GATT. The approach adopted in the report was based on a very simple question: how could environmental issues be accommodated within the existing body of international trade law without disrupting it?

Since then, the early explorations of the trade/environment nexus clearly reflected this main analytical perspective: a perspective adopted for many years by trade theorists, and often referred to as "single-minded free trade perspective" or "pro-trade bias."10 And the trade community, imbued with neoliberal economic thinking, argued that the environment could be accommodated within the basic paradigm of free trade, which represented the parameter to evaluate the legitimacy of environmental measures. In other words, it "was the trade community viewing environmental measures, rather than the environmental community viewing the trade system."11 As a result, scholars have long approached the trade/environment nexus by identifying and analyzing environmental issues that have raised questions of consistency with the GATT, and then applying GATT rules to such issues. ${ }^{12}$ The GATT itself has contributed to

GATT, Industrial Pollution Control and International Trade, Note by the GATT Secretariat, L/ 3538, June 9, 1971.

10 J. Owen Saunders, 'Trade and Environment: The Fine Line Between Environmental Protection and Environmental Protectionism' (1992) 47(4) International Journal 723, 726. Robert Howse and Makau Mutua, 'Protecting Human Rights in a Global Economy: Challenges for the World Trade Organization' (2002) International Center for Human Rights and Democratic Development, Policy Paper. Sungjoon Cho, 'Linkage of Free Trade and Social Regulation: Moving Beyond the Entropic Dilemma' (2005) 5 Chicago Journal of International Law 626,640. This approach has also been criticized for leading to a kind of 'myopic view' of the trading system. See Philip Nichols, 'Trade Without Values' (1996) 9o Northwestern University Law Review 658, 701.

11 Charles S. Pearson, 'The Trade and Environment Nexus: What is New Since '72?' in Durwood Zaelke et al. (eds.), Trade and the Environment. Law, Economics, and Policy (Island Press, 1993) pp. 23-4.

12 See e.g. Frederic L. Jr. Kirgis, 'Effective Pollution Control in Industrialized Countries: International Economic Disincentives, Policy Responses, and the GATT' (1972) 70 Michigan Law Review 859; James Cameron and Jonathan Robinson, 'The Use of Trade Provisions in International Environmental Agreements and their Compatibility with the GATT' (1991) Yearbook of International Environmental Law 3; Thomas J. Shoenbaum, 'Free International Trade and Protection of the Environment: Irreconcilable Conflict?' (1992) 86 American Journal of International Law 70o; Robert Housman and Durwood Zaelke, 'Trade, Environment, and Sustainable Development: A Primer' (1992) 15 Hastings International \& Comparative Law Review 535; McDorman, 'The 1991 U.S. - Mexico GATT Panel Report' (n 5); Thomas E. Skilton, 'GATT and the Environment in Conflict: The Tuna-Dolphin Dispute 
the debate, starting from the assumption that environmental laws and regulations are subject to the trade regime's control, ${ }^{13}$ as perfectly illustrated by the 1992 Trade and Environment Report: “... under GATT rules, governments can employ many different measures to protect and improve the local environment ... There is also nothing in the GATT that prevents contracting parties from taxing or regulating domestic producers who engage in polluting activities." ${ }^{14}$

Similarly, the EMIT group, established in 1972, despite the quite broad title 'Group on Environmental Measures and International Trade', had been conceived with the very same mindset. The EM IT group was created with the specific purpose of trying to "ensure that the efforts of governments to combat pollution did not result in the introduction of new barriers to trade or impede the removal of existing barriers." ${ }^{15}$ Once again, the ultimate goal remained economic in nature. ${ }^{16}$

The very fact that the relationship between trade and environmental objectives has been framed as "trade and ..." already presupposes a certain perspective on the issue: constructing certain values as 'trade values' and others as 'non-trade values' at some level favors the former over the latter when it comes to defining their relationship. ${ }^{17}$ And representatives of the environmental community have themselves been framing the relationship in these terms. The Stockholm Conference, in the part of its Action Plan that dealt with the relationship between trade and the environment, adopted principles similar to those suggested in the 1971 GATT study. Recommendation 104, for instance, entrusted the United Nations (UN) with the task to identify "the major threats

and the Quest for an International Conservation Strategy' (1993) 26 Cornell International Law Journal 455; Steve Charnovitz, 'A Taxonomy of Environmental Trade Measures' (1993) 6(1) Georgetown International Law Review 1; John H. Jackson, 'World Trade Rules and Environmental Policies: Congruence or Conflict?' (1992) 49 Washington and Lee Law Review 1227; Ernst-Ulrich Petersmann, 'International Trade Law and International Environmental Law. Prevention and Settlement of International Environmental Disputes in GATT' (1993) Journal of World Trade 43.

13 Patti Goldman, 'Resolving the Trade and Environment Debate: In Search of a Neutral Forum and Neutral Principles' (1992) 49 Washington \& Lee Law Review 1279.

14 GATT, Trade and the Environment (1992), 12 (emphasis added).

15 GATT, 'GATT, The Uruguay Round and the Environment' (1991) 85 GATT Focus 3.

16 It should not come as a surprise, then, that environmentalists feared that the Group would end up "subjugating environmental protections to trade's regimes as opposed to finding some way of reconciling the concerns of both trade and environmental interests." Housman and Zaelke, 'Trade, Environment, and Sustainable Development' (n 12) 572. Dunoff, 'Rethinking International Trade' (n 7) 383. 
to exports ... that arise from environmental concerns." ${ }^{18}$ Twenty years later, the text of Agenda 21 was drafted in accordance with the line adopted by the GATT Secretariat in its 1992 Report on Trade and the Environment, calling for the compatibility of environmental trade measures with 'international obligations' - namely the GATT — rather than requiring the compatibility of these 'international obligations' with environmental necessities. ${ }^{19}$ And even during the negotiations of specific multilateral environmental agreements, this trade-centered approach continued to characterize the discussions. During the negotiation of the Montreal Protocol for the Protection of the Ozone Layer, for instance, the participants invited a legal expert from the GATT Secretariat to advise them on the compatibility of the trade restrictions envisaged in the Protocol with multilateral trade rules. ${ }^{20}$

Everyone was looking to the GATT to define what environmental measures should be allowed. It was the trade community who set the rules of the game and who, guided by the prevailing neoliberal narrative, defined what constituted a 'trade issue' and what did not, what constituted the 'rule' and what was an 'exception'. For its part, the environmental community, young and lacking a united front, found itself forced in a corner, incapable of effectively challenging the elite's supremacy. ${ }^{21}$ As a result, environmental measures were depicted

18 United Nations Conference on the Human Environment, An Action Plan for the Human Environment, A/CONF.48/5 (Feb. 9, 1972) [hereinafter Stockholm Action Plan], Recommendation 104(a).

19 United Nations Conference on Environment and Development, Rio de Janeiro, Brazil, June 3-14, 1992, Agenda 21: Programme of Action for Sustainable Development, U.N. Doc. A/ CONF.151/26 (1992) [hereinafter Agenda 21], para. 2.22(c). See Charles Arden-Clarke, 'An Action Agenda for Trade Policy Reform to Support Sustainable Development: A United Nations Conference on Environment and Development Follow-Up', in Zaelke et al. (eds.), Trade and the Environment (n 11) 73, 4.

$20 \quad$ Housman and Zaelke, 'Trade, Environment, and Sustainable Development' (n 12) 580.

21 Furthermore, this same approach has characterized the way in which the GATT system has been dealing with measures designed to serve a much broader array of non-trade or non-economic values. As a matter of fact, free traders were seeing environmental regulation as just one of the many challenges faced by the world trading system, such as antitrust policy, labor, or health standards. GATT, Trade and the Environment (n 14). The 1971 GATT study, for instance, recognized that environmental "standards or their enforcement may well cause distortions of, or discrimination in foreign trade but the problems will not be different in kind from those created by standards used to promote health or safety in general." GATT, Industrial Pollution Control and International Trade (n 9) 2. See e.g. John H. Jackson, 'International Economic Problems and their Management in the 21st Century' (1979) 9 Georgia Journal of International \& Comparative Law 497; 'Dolphins and Hormones: GATT and the Legal Environment for International Trade after the Uruguay Round' (1992) 14(3) University of Arkansas at Little Rock Law Journal 429, 438; 'GATT and the Future of International Trade Institutions' (1992) XVIII(1) 
as a threat to the smoothness and speed of international trade flows and to the integrity of the international trade regime as a whole. A threat that had to be removed and, to the extent that total elimination was not possible, limited and kept at bay.

\subsection{Who's Afraid of Environmental Measures? -Part I. Environmental Measures as Non-Tariff Barriers}

The main consequence of looking at environmental measures through the lenses provided by the international trade law framework has been a partial, and somehow misleading reading of such measures. Translating environmental principles and norms in economic terms means that environmental laws and regulations are only seen as non-tariff barriers, capable of disrupting the whole trading system, while the values they embody are not fully—if at all — captured. ${ }^{22}$

The environment made its first appearance on the stage of GATT talks precisely when the issue of non-tariff barriers (NTB s) first emerged. Tariff negotiations had been the main item of business in the first six GATT negotiation rounds, up until the Kennedy Round, which was concluded in $1967 . .^{23}$ Once tariffs were reduced, other types of (non-tariff) barriers began to surface and, starting from the Tokyo Round, GATT parties have been focusing most of their efforts on addressing these newly emerged, and potentially much more dangerous, types of trade barriers. ${ }^{24}$ They can be more dangerous because

Brooklyn Journal of International Law 11; 'International Economic Law: Reflections on the "Boilerroom" for International Relations' (1995) 10(2) American University Journal of International Law \& Policy 595; 'Reflections on International Economic Law' (1996) 17(1) University of Pennsylvania Journal of International Economic Law 17, 25; and 'Reflections on Constitutional Changes to the Global Trading System' (1996) 72 Chicago-Kent Law Review 511 .

22 Dunoff, 'Rethinking International Trade' (n 7) 355. According to DiMatteo et al, the situation did not change with the advent of the wTO, which seemed to still largely ignore nontrade concerns, as its "monolithic mandate of liberalising international trade generally does not allow the consideration of legal or ethical factors involving the environment, animal rights, consumer rights, labor rights, or sovereignty." Larry A. DiMatteo et al., "The Doha Declaration and Beyond: Giving Voice to Non-Trade Concerns Within the WTO Trade Regime' (2003) 36 Vanderbilt Journal of Transnational Law 95, 133. See also Nichols, 'Trade Without Values' (n 10) 66o.

23 As noted in the 196o Annual Review of the Work of the GATT, the Agreement "was negotiated primarily as a tariff agreement and its trade rules are essentially designed to prevent the nullification, by other kinds of restrictive measures, of the tariff concessions negotiated between contracting parties." GATT, The Activities of GATT 1959/6o (Geneva, 1960), 8.

24 The Tokyo Declaration specifies that "the negotiations are to cover tariffs, non-tariff barriers and other measures which impede or distort international trade in both industrial and agricultural products, including tropical products and raw materials, whether in primary 
non-tariff barriers are much more diversified, changeable, and hence more difficult to grasp than tariffs. ${ }^{25}$ Often, they are adopted for perfectly legitimate reasons, such as national security, public safety, or environmental protection. Nevertheless, they might create obstacles to trade and, to the extent that they do, they should be removed. ${ }^{26}$

At first, their removal was motivated by the fear that they might bring back the specter of protectionism, the very evil that the GATT drafters worked so hard to defeat and eradicate. Although free traders acknowledged that environmental measures could sometimes be adopted for legitimate purposes, they always emphasized the benefits of free trade and the "dangers of 'oldfashioned' protectionism masquerading as environmental concern." ${ }^{27}$ Over time, however, the meaning of 'free trade', around which the GATT system had been built, began to change and, rather than referring simply to a trade free from discrimination against foreign countries, as it had been envisioned by the GATT founders, it started to gain a broader meaning, as a trade free from burdens and government intervention. The latter, according to neoliberal economic theory, should have been kept to a minimum, regardless of its more or less legitimate purpose, stemming from the belief that "naturally functioning markets are better than those structured by government intervention."28 Liberalized trade was therefore portrayed as even conducive to the fulfilment of environmental goals, as it resulted in economic growth which, in turn, enabled governments to raise resources for a variety of purposes, including environmental protection, enabled technologies aimed at environmental protection to be imported where they had not been developed yet, and might even lead to a shift in production patterns with beneficial environmental effects. ${ }^{29}$

form or at any stage of processing." GATT, GATT Activities in 1973 (Geneva, 1974), 18. See Gilbert R. Winham, International Trade and the Tokyo Round Negotiations (Princeton University Press, 1985), p. 17.

25 GATT, GATT Activities in 1973 (n 24) 26.

26 Steven Shrybman, 'International Trade and the Environment: An Environmental Assessment of the General Agreement on Tariffs and Trade' (1990) 20(1) The Ecologist 30.

27 Mark Williams, 'International Trade and the Environment: Issues, Perspectives and Challenges' (1993) 2(4) Environmental Politics 80, 89; Shoenbaum, 'Free International Trade' (n 12) 715-6.

28 Williams, 'International Trade and the Environment' (n 27) 89.

29 This theory posits that the demand for environmental quality rises with the income, as reflected in the Environmental Kuznets Curve model. See Jagdish Bhagwati, 'The Case for Free Trade' (1993) Scientific American. James K.R. Watson, The WTO and the Environment (Routledge, 2013). Peter Newell, Globalization and the Environment: Capitalism, Ecology and Power (John Wiley \& Sons, 2013). 
The use of trade measures to address environmental problems, on the other hand, was simultaneously described as inefficient and often ineffective, as well as dangerous for international trade and unjustifiable on economic grounds. ${ }^{30}$ And it did not take long before business interests in several countries began enlisting the aid of trade rules in the GATT or in Free Trade Agreements (FTA s) to attack environmental regulations as non-tariff barriers, blinded by the fear of the potential harm they might suffer and oblivious to the inherent environmental and societal value of such regulations. ${ }^{31}$ The first dispute ever decided under the 1988 United States-Canada Free Trade Agreement (USCFTA), for instance, dealt with certain provisions of the Canadian Fisheries Act, ${ }^{32}$ which required that all fish caught for commercial purposes in Canadian waters must be landed first in Canada for biological sampling, which was challenged by the United States (US) as violating Canada's obligations under the FTA. ${ }^{33}$ The same agreement was then invoked on many other occasions by both governments to attack environmental and resource-conservation initiatives on both sides of the border, such as Canadian acid-rain-reduction programs or fish conservation policies, and US asbestos regulations and paper-recycling laws. ${ }^{34}$ As a result of the pressures caused by such threats, many environmental measures were modified or removed one after the other. So, a reforestation program introduced in British Columbia was scrapped immediately after being attacked by the US timber industry as an illegitimate subsidy, and a US bill banning the importation on American soil of wild-caught birds was first delayed and ultimately watered down in Congress because of its alleged incompatibility with the GATT. ${ }^{35}$ Similarly, the European Communities (EC) and Canada have relied on the text of the GATT, and in particular on Article III:2, to challenge a tax on petroleum imposed by the United States on the basis of the so-called Superfund Act of $1986 .^{36}$

$30 \quad$ See e.g. World Bank, World Development Report 1992 (Oxford University Press, 1992), p. 67; and Ingo Walter, 'Pollution and Protection: US Environmental Controls as Competitive Distortions' (1974) 110 Weltwirtschaftliches Archiv, 104, 112.

31 Steven Shrybman, 'Trading Away the Environment' (1991/92) 9(1) World Policy Journal 93, 104. Housman and Zaelke, 'Trade, Environment, and Sustainable Development' (n 12) 575.

32 Fisheries Act, R.s.C., 1985, c. F-14.

33 In re Canada's Landing Requirement for Pacific Coast Salmon and Herring, Canada-US Trade Commission Panel, Oct. 16, 1989, 2 тCT 7162. See Housman and Zaelke, 'Trade, Environment, and Sustainable Development' (n 12) 575 .

34 Shrybman, 'Trading Away the Environment' (n 31 ) 93.

35 Lori Wallach, 'Hidden Dangers of GATT and NAFTA', in Ralph Nader et al. (eds.), The Case Against Free Trade 23-64 (North Atlantic Books, 1993), p. 26.

36 Superfund Amendments and Reauthorization Act, 42 U.s.c. $\S 9601$ et seq. (1986). This Act, passed on October 17, 1986, amended the Comprehensive Environmental Response, 


\subsection{Who's Afraid of Environmental Measures?-Part II. The Harmonization Agenda}

The story does not end here. Even when a measure was found to be a lawful trade restriction rather than disguised protectionism, the very fact that different countries had different environmental standards, policies, and regulations, was seen as a trade barrier in itself. Faced with the impossible task of removing these standards or regulations as they were all 'legitimate', the solution designed by the trade community has been to harmonize them. Again, USCFTA perfectly illustrates this agenda. Chapters six and seven of the Agreement required the parties to harmonize technical and agricultural standards, and Canada, as part of the bargain, "agreed to 'work toward equivalence' with a risk-benefit regulatory model for pesticide registration." ${ }^{37}$ This bargain, however, required Canada to abandon a more stringent system and ultimately settle for lower levels of environmental protection, forcing the country to "accept US food imports that contain 30 per cent more pesticide residues than were allowed under their national laws before [the agreement]"38

The early activities of the European Community in the context of environmental management were equally aimed at harmonization. Being motivated primarily by economic concerns, the goal of the Community was to unify the common market and eliminate obstacles that would prevent free movement of products between the Member States. ${ }^{39}$ In fact, according to Article 2 of the Treaty of Rome (EEC Treaty),

It shall be the aim of the Community, by establishing a Common Market and progressively approximating the economic policies of Member States, to promote throughout the Community a harmonious development of economic activities, a continuous and balanced expansion, an

Compensation, and Liability Act (CERCLA) of 1980. The Superfund Act, among other things, re-imposed an excise tax on petroleum at higher rates, re-imposed a tax on certain chemicals, and imposed a new tax on certain imported substances produced or manufactured from taxable feedstock chemicals. The dispute brought by the EC and Canada was addressed by a GATT panel in June 1987. See Report of the GatT Panel, United StatesTaxes on Petroleum and Certain Imported Substances, L/6175, 34S/136 (June 17, 1987).

37 Shrybman, 'International Trade and the Environment' (n 26) 33.

38 Wallach, 'Hidden Dangers of GATT and NAFTA' (n 35) 26.

39 See Christina Ruth Meltzer, 'The Environmental Policy of the European Economic Community to Control Transnational Pollution-Time to Make Critical Choices' (1990) 12 Loyola of Los Angeles International \& Comparative Law Review 579, 586-7; Owen Lomas, 'Environmental Protection, Economic Conflict and the European Community' (1988) 33 Mc Gill Law Journal 5 o6. 
increased stability, an accelerated raising of the standard of living and closer relations between its Member States. ${ }^{40}$

Because the Council of the Community lacked an environmental mandate and could only issue directives "for the establishment or functioning of the common market," environmental initiatives were justified on the basis that they removed obstacles to the creation and functioning of the common market. ${ }^{41}$ Such initiatives mostly relied on two provisions of the Treaty of Rome, Articles 100 and $235 .{ }^{42}$ Article 100, in the relevant part, reads:

The Council shall, acting unanimously on a proposal from the Commission, issue directives for the approximation of such provisions laid down by law, regulation or administrative action in Member States as directly affect the establishment or functioning of the common market. ${ }^{43}$

Differences in national standards-including environmental differenceswere seen as creating technical barriers to trade, as even the GATT Secretariat had stated in its 1971 study: "very substantial trade barriers can and do arise from differences in national standards ... even when no protection is intended." ${ }^{44}$ Article 100 was therefore often used to justify directives that, although cloaked in environmental terms, were actually part of a program to harmonize national laws to remove distortions of competition, being adopted pursuant to the 'General Program for the elimination of technical barriers to trade within the Community' 45 On this basis, in 1970, the Community adopted a Directive regarding petrol-engine vehicles that, among other things, set limit

40 Treaty Establishing the European Economic Community, Mar, 25, 1957, 298 U.N.T.s. 11 [hereinafter Rome Treaty], Art. 2.

41 Lomas, 'Environmental Protection' (n 39) 506.

42 Article 235 of the Rome Treaty reads: "If action by the Community should prove necessary to attain, in the course of the operation of the common market, one of the objectives of the Community and this Treaty has not provided the necessary powers, the Council shall, acting unanimously on a proposal from the Commission and after consulting the European Parliament, take the appropriate measures."

43 Rome Treaty, Art. 100.

44 GATT, Industrial Pollution Control and International Trade (n 9) 12. See Auke Haagsma, 'The European Community's Environmental Policy: A Case-Study in Federalism' (1988) 12(2) Fordham International Law Journal 312, 316.

45 Council Resolution of May 28, 1969, 12 O.J. C 76/1 (1969). See Wolfgang E. Burhenne and Thomas J. Shoenbaum, 'The European Community and Management of the Environment: A Dilemma' (1973) 13 Natural Resources Journal 494, 499. 
values for emissions of carbon monoxide and hydrocarbons. ${ }^{46}$ This Directive, just as those that followed over the next few years, ${ }^{47}$ was not motivated by environmental concerns: the Community had recognized that the fact that some Members States were introducing more stringent measures than others to control these emissions risked creating barriers to intra-Community trade and thus prejudicing the creation of a common market. ${ }^{48}$ As a result, the only obligation placed on Member States was to not introduce values more stringent than those set out in the Directive and, by doing so, it preempted planned legislation in several European countries, such as Germany, that would have required stricter standards. ${ }^{49}$

The risk of pursuing such 'harmonization agenda', as depicted by the two examples provided above, is that environmental rules and standards might be compromised on the lowest level. As long as concern for the environment is not a factor and environmental policy is controlled by an economic agendawhether that of the European Community or of the international community at large - the picture does not seem promising for the environment.

\subsection{The Exception to the Rule}

This trade-centered approach has led to a system where free trade is the rule and environmental protection is the exception; where trade law is the framework of reference, while environmental measures are simply the object to be evaluated on the basis of that framework. The word 'environment' does not even appear throughout the pages of the GATT, the Rome Treaty, or most trade agreements negotiated over the twentieth century up to the early 199 os. $^{50}$

46 Council Directive of 6 February 1970 on the approximation of the laws of the Member States relating to the type-approval of motor vehicles and their trailers, $70 / 156 /$ EEC O.J. (L 42).

47 Council Directive 70/157/EEC of 6 February 1970 on the approximation of the laws of the Member States relating to the permissible sound level and the exhaust system of motor vehicles, as amended by Directives Council Directives 73/350/EEC, 1973 O.J. (L 321), 77/ 212/EEC, 1977 O.J. (L 66), 84/372/EEC, 1984 O.J. (L 196), 84/424/EEC, 1984 O.J. (L 238), 87 / 354/EEC, 1987 O.J. (L 192), 89/491/ EEC, 1989 O.J. (L 238), 92/97/EEC, 1992 O.J. (L 371), 96/ 20/EC, 1996 O.J. (L 92), 1999/101/EC, 1999 O.J. (L 334), 2007/34/EC, 2007 O.J. (L 155).

48 Lomas, 'Environmental Protection' (n 39) 525.

49 Burhenne and Shoenbaum, 'The European Community' (n 45) 501.

50 Free Trade Agreement, EU-Switzerland-Liechtenstein, July 22, 1972; Free Trade Agreement, EU-Iceland, Dec. 19, 1972; Free Trade Agreement, EU-Norway, May 14, 1973; Asia-Pacific Trade Agreement, July 31, 1975; Free Trade Agreement, Australia-Papua New Guinea, Nov. 6, 1976; South Pacific Regional Trade and Economic Cooperation Agreement, Jan. 1, 1981; Latin American Integration Association, Aug. 12, 1980; Free Trade Agreement, United States-Israel, Apr. 22, 1985; Global System of Trade Preferences among Developing 
When these treaties were drafted, the environment was not thought of as a subject requiring international cooperation and its potential relationship with trade was still largely ignored, leading to their substantive provisions being crafted "with little if any regard for the environmental consequences that may flow from them." 51

Because of the late emergence of the environment issue vis-à-vis international cooperation on trade matters, there is no mention of the environment in any trade agreement signed before the 1970 s and the first attempts to regulate the environment — both at the domestic and international level—necessarily had to depend on states' economic powers. Once the question of the relationship between the two bodies of law was first tabled and the first disputes arose, Article XX of the GATT - an exception clause - was immediately presented as the natural and sole possible entry point for environmental considerations, while there seemed to be no room for the environment in any of the agreement's substantive provisions. In fact, none of the 'rules' of the GATT or any other trade agreement allowed for environmental differentiation or for the pursuit, in any other way, of environmental objectives. It was impossible, for instance, to defend an environmental internal regulation on the basis that it did not discriminate between two products - for instance a bag of shrimps that came from a country that requires turtle excluder devices and one that did not ${ }^{52}$ - arguing that the two products were not like' under Article III:4 of the GATT. ${ }^{53}$ In other words, states were not allowed "to use the process characteristic as the basis for trade restrictive measures" as the "result would be to open a

Countries, Apr. 13, 1988. There are of course some exceptions, such as the 1986 Single European Act (SEA) and NAFTA.

$5^{1} \quad$ Shrybman, 'Trading Away the Environment' (n 31 ) 94.

$5^{2}$ This example in inspired by the facts of the well-known wTo dispute US-Shrimps.

53 According to Article III:4 of the GATT, "The products of the territory of any contracting party imported into the territory of any other contracting party shall be accorded treatment no less favorable than that accorded to like products of national origin in respect of all laws, regulations and requirements affecting their internal sale, offering for sale, purchase, transportation, distribution or use. The provisions of this paragraph shall not prevent the application of differential internal transportation charges which are based exclusively on the economic operation of the means of transport and not on the nationality of the product." (emphasis added). It is important to stress that the prohibition in Article III:4 of the GATT only applies to 'like' products. For an analysis of the notion of likeness in international trade law, see e.g. Robert E. Hudec, "Like Products": The Differences in Meaning in Articles I and III', in Thomas Cottier and Petros Mavroidis (eds.), Regulatory Barriers and the Principle of Non-Discrimination in World Trade Law (University of Michigan Press, 2000), pp. 101-123; Won-Mog Choi, 'Like Products' in International Trade Law (Oxford University Press, 2003). 
Pandora's box of problems that could open large loopholes in the GATT." 54 The only available option would have been to rely on Article Xx.

Rather than being able to enter trade agreements through the main door, the environment was allowed access through a small crack in a window, the window in question being an exception clause. Most trade law instruments, in fact, contain a clause labelled 'general exceptions', recognizing that countries might want to pursue perfectly legitimate non-economic goals, even when in order to do so they adopt a trade restrictive measure, provided that certain conditions are met. And, despite not mentioning the term 'environment', it is precisely in these exceptions that environmentalists were expected to find some comfort.

GATT Article XX - replicated in almost all other trade agreements signed in the years that followed the signing of the GATT —allows GATT parties to adopt measures inter alia "(b) necessary for the protection of human, animal, and plant life or health; or (g) relating to the conservation of exhaustible natural resources if such measures are made effective in conjunction with restrictions on domestic production or consumption," as long as the requirements of the chapeau are fulfilled. ${ }^{55}$ Similarly, Article 36 of the Treaty of Rome "allows member states to adopt measures which are prima facie incompatible with Articles 30 to 34 for the purpose of protecting a series of non-economic values such as ... the protection of human health or life, animals or plants," assuming once again that certain conditions are met. ${ }^{56}$

Exceptions of this kind were not new. Rather, they had been part of bilateral treaties of commerce since their inception, together with those covering measures adopted for national defense reasons or to organize the parties' internal trade. As demonstrated by their drafting history, these provisions

54 Jackson, 'World Trade Rules and Environmental Policies' (n 12) 1243. The GATT's reluctance to take into account process and production methods (PPM s) reflects one of the underlying differences between the trade and environmental communities: the former concerned only with products and the latter with processes. For a recent analysis of this issue, see David Sifonios and Andreas Ziegler, "Tuna-Dolphin Forever"? The Development of the PPM Debate Related to Trade and Environment in the WTO' (2020) 12 Indian Journal of International Economic Law 106.

55 According to the chapeau of Article Xx, "nothing in this Agreement shall be construed to prevent the adoption or enforcement by any contracting party of measures" falling under one of the subsequent subparagraphs "subject to the requirement that such measures are not applied in a manner which would constitute a means of arbitrary or unjustifiable discrimination between countries where the same conditions prevail, or a disguised restriction on international trade."

56 Damien Geradin, Trade and the Environment. A Comparative Study of EC and US Law (Cambridge University Press, 1997), p. 13. 
were originally designed to cover a wide variety of legitimate public policy objectives - environmental protection, however, not being one of them. And in this regard, GATT Article XX was not different from all its predecessors.

\subsection{The Real Story of 'Environmental' Exceptions or 'On How They Became Environmental'}

Mr. fH.M. Catudal (United States): "What is the corresponding safeguard? ... If you are trying to protect yourself, say, from the bubonic plague, it is to exclude any article that might give rise to bubonic plague. ${ }^{.57}$

On July 16, 1947, one of the Commissions of the Preparatory Committee of the UN Conference on Trade and Employment-Commission A-met in the Palais de Nations in Geneva to discuss, inter alia, the exact formulation of Article $37(\mathrm{~b})$ of the draft, which later became xx(b) of the GATT. Debating whether there was a need to add an explanatory note to the phrase "necessary for the protection of human, animal, and plant life or health," the US delegate, Mr. Catudal, mentioned the bubonic plague as an example of a type of risk that the clause in question could be used to address. Without entering the merits of the debate, it suffices to say that all the other delegates followed the American example and referred to the regulations that Article $37(\mathrm{~b})$ was designed to protect as 'sanitary regulations', adopted to prevent the spreading of diseases. ${ }^{58}$

In a later meeting, in February 1948, the Committee clarified once again that the measures to be published under Article $37(\mathrm{~b})$ were "quarantine and other sanitary regulations. ${ }^{59}$ This reading of the clause is not surprising given the legislative history of similar provisions in treaties of commerce up until the 1990s. The Treaty of Commerce between Italy and Switzerland, signed in 1904, for instance, allowed the parties to introduce export, import, or transit prohibitions "par égard à la police sanitaire et en vue de la protection des animaux, ainsi que des plantes utiles contre les maladies, les insectes et parasites nuisibles." 60

$57 \quad \mathrm{E} / \mathrm{PC} / \mathrm{T} / \mathrm{A} / \mathrm{PV} / 30$ (July 16,1947$), 11$.

$5^{8}$ See e.g. the statements of Mr. Roux (France), or Mr. Cherry (South Africa): "We have been considerably puzzled as to how exactly a country will provide proof that it would take steps, if say someone should say a particular disease did exist in a country when, in fact, that particular disease does not exist in the country." E/PC/T/A/PV/3O, 9, 13 .

59 E/CONF.2/C.3/SR.35 (Feb. 14, 1948).

6o Treaty of Commerce, Italy-Switzerland. 
The Italy-Switzerland Treaty, just as any other trade agreement negotiated until the 199os, did not mention the environment and did not in any way suggest that the clause could be used to justify measures designed to protect the environment broadly speaking. ${ }^{61}$ Similarly, the 1927 Preliminary Draft for the International Agreement for the Abolition of Import and Export Prohibitions and Restrictions, which was used as a blueprint for the GATT, featured an exception covering restrictions solely "for the protection of public health or for the protection of animals or plants against disease, insects, and harmful parasites."62

In those years, and up until the 1970s, environmental protection was simply not a public issue, as it was not during the negotiations of the GATT, when these debates were taking place. Nor was it a public issue in 1950, when the Treaty of Rome was being drafted. In fact, environmental protection does not in itself figure in Article 36 of the Treaty: ${ }^{63}$ we will have to wait until 1979 for Article 36 to be considered, among other things, as an environmental exception. It had already been argued that environmental measures may be designed to protect some of the values listed therein, ${ }^{64}$ but it was only with the establishment of the rule of reason in Cassis de Dijon that the environment could truly penetrate Article 36. In its famous decision, the European Court of Justice (ECJ), recognized that Member States may, when adopting measures which applied equally to domestic and imported products, restrict intra-Community trade for reasons other than those specifically recognized by Article $36: 65$

Obstacles to movement within the Community resulting in disparities between the national laws relating to the marketing of the products in question must be accepted in so far as those provisions may be recognized as being necessary in order to satisfy mandatory requirements relating in particular to the effectiveness of fiscal supervision, the protection of

61 The fact that some treaties did not use the word 'sanitary' is not here considered meaningful in terms of what the objective and scope of the clause was. But see Steve Charnovitz, 'Exploring the Environmental Exceptions in GATT Article XX' (1991) 25 Journal of World Trade 37 .

62 Preliminary Draft for the International Agreement for the Abolition of Import and Export Prohibitions and Restrictions (1927 World Economic Conference).

63 Like GatT Article xx, Article 36 of the Eec Treaty simply refers to "the protection of human health or life, animals or plants."

64 See B. Jadot, 'Observations-Mesures Nationales de Police de l'Environnement, Libre Circulation des Marchandises et Proportionalité' (1990) Cahiers de Droit Européen 408, 411.

65 See Derrick Wyatt and Alan Dashwood, European Community Law (Sweet \& Maxwell, 3rd ed., 1993) p. 23o; Stephen Weatherill and Paul Beaumont, EU Law (Penguin, 1993), p. 439. 
health, the fairness of commercial transactions and the defense of the consumer. ${ }^{66}$

And the few doubts whether environmental protection did indeed fall within the Cassis de Dijon requirements were definitively removed in 1980, when the EC Commission underlined the importance of environmental protection as a potential limitation on the prohibition contained in Article $30 .{ }^{67}$ And a few years later, in the Danish Bottles case, the Advocate General "accepted that environmental protection was an imperative requirement justifying measures prima facie contrary to Article 30." 68

For many years, after the drafting of the GATT, no mention was made of the environment being somehow associated to the exceptions of Article xx. When the issue of non-tariff barriers emerged, in the early 1970s, it was acknowledged that some might have perfectly legitimate reasons - such as national security, or public health safety — but the focus was, once again, on health and safety, rather than on the environment per se. ${ }^{69}$ Twenty years later, in the Tuna/Dolphin case, the panel itself defined the measures covered by Article $\mathrm{xx}(\mathrm{b})$ as 'sanitary measures', when assessing the applicability of the clause to the US import prohibition. ${ }^{70}$

Along very similar lines, paragraph (g) of Article $\mathrm{xx}$, was initially thought of as a much more limited exception, being the environment once again far from the drafters' minds. The reasons for the amendment proposed by the Australian delegation to the text of then Article $37(\mathrm{~g})$ are quite self-explanatory in this regard:

Pre-war experience in Australia showed that it was necessary to prohibit the exportation of iron ore, partly on the grounds that it seemed likely to be used for military purposes by the purchasing country. It is therefore the view of the Australian Delegation that there should be in the Charter, a provision enabling a Member to prohibit exports of such essential materials in the long term interests of its security. ${ }^{71}$

66 Case C-120/78, Rewe-Zentral AG v. Bundesmonopolverwaltung fiir Branntwei, 1979, E.C.R. $649,662$.

67 Geradin, Trade and the Environment ( $\mathrm{n}_{56}$ ) p.14.

68 Cameron and Robinson, 'The Use of Trade Provisions' (n 12) 25.

69 GATT, GATT Activities in 1972, 26.

70 Report of the GATT Panel, United States - Restrictions on Imports of Tuna, DS21/R-39S/155 (Sept. 3, 1991) (not adopted) [hereinafter US-Tuna I], para. 5.26. This is the first dispute where the Respondent relied on Article $\mathrm{xx}(\mathrm{b})$ to justify an allegedly environmental measure. In the previous disputes, only paragraph $(\mathrm{g})$ had been raised. 
The mention of minerals, such as iron ore or manganese, ${ }^{72}$ and the reference to national security in the context of arguments made by several delegates that export restrictions should be permitted for the preservation of scarce natural resources, has led many to argue that the phrase "exhaustible natural resources," as written in 1947, only referred to finite resources, such as minerals, and not to biological resources, such as plants or animal species. If it is true that the drafting history of GATT Article $\mathrm{Xx}(\mathrm{g})$ "does not demonstrate an intent on the part of the framers to exclude "living" natural resources from the scope of application"73 of the provision, it is also true that in no circumstance they expressed their intention to include such resources. And as a result, up until the Appellate Body report in US-Shrimps in 1998, the parties to the WTO were still debating as to the precise scope and content of the clause. ${ }^{74}$

\subsection{The Indeterminacy of Trade Law and The Neoliberal Turn}

The late emergence of the environment issue vis-à-vis international cooperation on trade matters explains why there is no mention of the environment in any trade agreement signed before the 1970s. However, it does not explain why, once the first disputes arose, the obvious conclusion seemed to be to relegate the environment to an exception clause, whether Gatr Article xx, Article 36 of the Treaty of Rome, or similarly worded clauses in regional and bilateral trade agreements. This was not necessarily the idea of the GATT founders, precisely because that very provision had been drafted with several legitimate domestic concerns in mind, none of which even remotely related to the environment. None of the GATT provisions had been drafted to address environmental concerns, yet Article Xx immediately became the sole solution. It was not, however, the only option. In a different, parallel scenario, one could imagine the environment entering the GATT through Article III rather than Article XX. In other words, when the first disputes broke out, a possible solution could have been to allow several kinds of trade-related environmental measures without finding a violation of national treatment, simply by defining the notion of 'like products' or of 'less favorable treatment' differently. Article xx would then only be used to justify quantitative restrictions and, more broadly, violations of Article XI of the GATT, as it was originally set up.

72 The example of manganese was used by the Brazilian delegate, Mr. Kafka, during a meeting held on November 18, 1946 (E/PC/T/C.II/QR/PV/5), 79.

73 Appellate Body Report, United States-Import Prohibition of Certain Shrimp and Shrimp Products, wT/DS58/AB/R (Oct. 12, 1998) [hereinafter US—Shrimps], fn. 114. Ibid., paras 127-8. 
The truth is that international trade law is, and always has been, largely indeterminate. It contains a series of "ambiguous and generally-worded principles," leaving the entire regime potentially compatible with a broad and diverse array of political choices and programs. ${ }^{75}$ Hudec describes the ambiguity of the GATT text as necessary to ensure sufficient flexibility in the law so to reflect whatever consensus prevailed at a particular point in time. ${ }^{76}$ The notion of 'non-discrimination', for instance, is susceptible to a number of different interpretations, and it has indeed been interpreted differently since the adoption of the GATT. For the architects of the post-war international trading order, the non-discrimination norm contained in GATT Article III was read as an 'anti-protectionism' norm, applicable against those internal measures that were motivated by protectionist intents. ${ }^{77} \mathrm{~A}$ few decades later, and in particular in the 1980s and 1990s, the concept of 'discrimination' came to be treated as more or less synonymous with the economic concept of market distortion. As a result, all measures which had a negative impact on international tradeeven when not protectionist in their purpose-began to fall under the scope of the norm and were therefore at risk of violating the GATT.

This change in understanding over the years was possible because nothing necessarily links the trade regime to a particular understanding of 'non-discrimination' and it has been explained with reference to a change in the ideational basis of the nature and purpose of the trade regime itself, from embedded liberalism to a resurgence of liberal economic thinking (neoliberalism).

Among post-war planners, the prevailing ideological orientation was embedded liberalism, which "combined limited and qualified support for free trade with a commitment to large-scale state interventionism." ${ }^{78}$ Free trade was read as 'trade free from discrimination', and the principle of non-discrimination

75 Lang, World Trade Law After Neoliberalism (n 3 ) 5 .

76 According to Hudec, "the ability to express ideas in this vague and cloudy manner allows the community to bring to bear whatever degree of consensus does exist. A suggestive statement, however ambiguous, provides something formal and official on which the community can focus its attitudes. The statement itself will point to the preferred result, and support expressed for that statement can create some pressure of consensus toward that end. Part of that pressure lies in the possibility that, faced with a specific case, the community may find itself willing to take a more positive stand than it has taken before. The ambiguous gesture invites such a development and furnishes a vehicle through which it may come about." Robert E. Hudec, 'The GATT Legal System: A Diplomat's Jurisprudence' (1970) 4 Journal of World Trade Law 615, 630, as quoted in Lang, World Trade Law After Neoliberalism (n 3) 204.

77 Lang, World Trade Law After Neoliberalism (n 3 ) 254.

78 Ibid., p. 4. 
represented the pillar on which the GATT was founded. As aptly put by Viner, " $[t]$ he case for equality of treatment as the general rule is a strong one. It is the only general rule in this field which is of general applicability." ${ }^{\prime 79}$ As the previous chapter has described, the GATT was created to avoid the trade wars of the 1930s, soon associated in the public eye not only with the Great Depression but with the horrors of the war. Discriminatory trade, on the other hand, was regarded as a dangerous threat to international peace. In the words, once again, from Viner, "tariff discriminations are invariably resented by the countries which are discriminated against, and three centuries of experience demonstrate that under all circumstances they operate to poison international relations and to make more difficult the task of maintaining international harmony." 80

As a result, the immediate priority of the GATT negotiators was to remove the more restrictive trade practices introduced over the course of the interwar period, as they risked subverting the core objectives of the regime they were attempting to create. ${ }^{81}$ The focus was in particular on border measures, such as quotas, foreign exchange restrictions, and licensing requirements, ultimately prohibited with the insertion of Article XI in the text of the GATT. As to internal measures, on the contrary, "only a few very specific categories were made visible as barriers to trade" while all the others "were implicitly understood to be normal or background regulation, never intended to be subject to GATT oversight." 82

The Tokyo Round of trade negotiations, which was concluded in 1979, witnessed a significant economic turmoil of global proportions, which "helped to erode political support for the normative priorities of embedded liberalism" and instead provided "the conditions for the re-emergence and restrengthening of a purer form of economic liberalism—neoliberalism," which

79 Jacob Viner, 'Conflicts of Principle in Drafting a Trade Charter' (1947) 25 Foreign Affairs 612,616 .

8 Ibid.

81 As explained by Srinivasan, "it is clear that the signatories viewed discriminatory treatment in international commerce, not as being unfair in some relevant sense ... but as subverting the broad objectives that signatories sought to promote through GATT." T.N. Srinivasan, 'Nondiscrimination in GATT/WTO: Was there Anything to Begin with and is there Anything Left? (2005) 4 World Trade Review 69, 74-5. See also Robert E. Hudec, Essays on the Nature of International Trade Law (Cameron May, 1999), pp. 227-250.

82 Lang, World Trade Law After Neoliberalism (n 3) 209. This reading of Article III of the GATT was possible because it was based on a shared understanding of the purpose and objectives of the trade regime, which was primarily 'shared' among the key negotiators. 
would quickly become the prevailing ideology in international trade governance for the coming decades. ${ }^{83}$

This transformation, which can be attributed to both the economic turmoil of the 1970s and the expansion in the number and diversity of GATT participants, and which could no longer guarantee the survival of the 'shared' consensus that had characterized the embedded-liberalism years, had a strong ideational basis. On the one hand, the notion of 'trade barrier' came to be regarded as synonymous to the idea of 'trade distortion'. According to neoliberal thinking, the goal of the trade regime was to remove all governmental interventions because distortive of international trade flows. ${ }^{84}$ As a result, the scope of application of the overall regime expanded, and virtually all aspects of countries' domestic policies became potentially subject to the GATT/WTO discipline as "potentially" trade-distortive. On the other hand, the regime came to be 're-imagined' as a marketplace, thus justifying the series of game theory explanations of the GATT which, became influential through the 1980s.

The GATT/WTO regime had significantly changed its character, becoming more formalized and 'technicalized', as well as motivated by economic and ideological concerns rather than the political ones that had inspired the founders of the regime. This transformation had significant influence on the interpretation and application of the principle of non-discrimination enshrined in Article III of the GATT, whose potentially "significant substantive bite" 85 was becoming apparent only in the context of the disputes that immediately followed the conclusion of the Tokyo Round. Indirectly, it had an equally significant influence on the way in which the relationship between trade and the environment was approached for several decades, contributing to the solidification of an approach that left no other space to the environment than exception clauses. The treatment of all forms of government intervention in the economy as trade-distortive and the focus on economic effects in the context of the likeness analysis under Article III - rather than on the distinction between legitimate domestic regulation and regulation with protectionist motives - resulted in a significant expansion of the prohibitive effect of the

83 Ibid., p. 222.

84 As David Kennedy put it, within neoliberal thought, "[l]aw emerged as a limit on the state - on the discretion of administrators and the mandate of legislators. Private rights, constitutional procedures, judicial review, and international obligations-all constrained the neoliberal state." David Kennedy, 'The "Rule of Law," Political Choices, and Development Common Sense', in David M. Trubek and Alvaro Santos (eds.), The New Law and Economic Development: A Critical Appraisal (Cambridge University Press, 2006), p. 138.

85 Lang, World Trade Law After Neoliberalism (n 3) 208. 
norm, leaving no space for environmental regulations other than that provided by Article Xx, an exception clause.

This approach was further exacerbated by the complete isolation in which the two communities continued working for years, unaware of each other's values and goals, and rarely perceiving their respective realms as even remotely interconnected. And the deep cultural differences between the two communities-the different languages, assumptions, and philosophical underpinnings — did nothing but deepen the divide, undermining any attempt of communication or interaction.

Rivalry

In the Spring of 1992, posters mysteriously appeared in Washington D.C., depicting GATTzilla, a gigantic monster, evocative of Japanese monster Godzilla, "chewing the globe, trampling the Capitol, and spewing DDT, while clutching a squealing dolphin." 86 The headline blared 'GATT is Coming. What You Don't Know Will Hurt You'. The posters had been plastered on the construction walls surrounding the building that housed the offices of the United States Trade Representative (USTR) and were soon followed by condemnatory advertisements in the New York Times and the Washington Post under the headline 'sabotage', announcing an approaching GATTastrophe, and displaying the slogan 'GATT—Guaranteeing A Toxic Tomorrow.' 87

These fervent protests had been triggered by the GaTT panel decision in the Tuna/Dolphin case, loudly criticized by environmentalists all over the Western hemisphere, who raged with fury and denounced free trade for blindly fostering the exploitation of natural resources, and for ultimately contributing to environmental destruction. ${ }^{88}$ The GATT was depicted as a sinister character

86 Jan C. McAlpine and Pat LeDonne, 'The United States Government, Public Participation, and Trade and Environment', in Zaelke et al. (eds.), Trade and the Environment (n 11) 203.

87 See Daniel C. Esty, Greening the GATT. Trade, Environment, and the Future (Institute for International Economics), p. 35. Jagdish Bhagwati, 'Trade and the Environment: The False Conflict?' in Zaelke et al. (eds.), Trade and the Environment (n 11) 161; and Sylvia Ostry, 'Energy Security and Sustainable Development: The WTO and the Energy Charter Treaty', in Marina Larionova (ed.), Making Global Economic Governance Effective: Hard and Soft Law Institutions in a Crowded World (Routledge, 2016), p. 131.

88 Report of the GATT Panel, US - Tuna I. In addition to threatening US environmental and conservation laws and policies, the decision was perceived as putting other domestic laws, as well as newly adopted multilateral environmental treaties, at risk of being GATTinconsistent. The European Parliament, for instance, had recently presented a proposal to introduce a ban on imports of tuna caught with driftnets or purse-seine nets, along very 
allowing 'big business' "a free hand to plunder the bounty of the natural world" to the point that free trade itself, in the view of certain environmentalists, could destroy the environment. ${ }^{89}$ Just like that, the (in)famous decision had raised the "specter" of an obscure international trade tribunal, with no environmental sensitivity or expertise, challenging and overriding environmental laws and regulations..$^{90}$ On the other side of the barricade, free-trade proponents welcomed the GATT panel decision with praise and excitement, as it was perceived as an important victory against the environmental lobby. They regarded the challenged US measure as an example of eco-colonialism, and as a dangerous attempt to influence the environmental standards of its trading partners, and began to fear that the GATT could be "in danger of becoming the latest sacrifice" of this out-of-control 'green gang'.91

The Tuna/Dolphin case was the first dispute that witnessed a direct collision of the two communities. As they first came in contact, environmentalists saw "free traders living in a world of economic theory that distracts them from environmental realities" and worried that, by liberalizing trade without taking the environment into account, countries would "lose the right to determine their own environmental standards" leading to ever-increasing environmental degradation. ${ }^{92}$ Free traders, on the other hand, looked on nervously as environmental agreements began incorporating trade measures, ${ }^{93}$ regarding

similar lines as the US ban. In light of the Tuna/Dolphin Decision, however, as warned by the Ec Commissioner for Cultural Affairs and Information, John Dondelinger, such legislation would not be compatible with the Community's obligations under the GATT. 'European Parliament Calls for Ec Ban on Imports of Tuna Caught by Purse-Seines', BNA Int'l Envt. Daily, Nov. 27. See Skilton, 'GATT and the Environment in Conflict' (n 12) 456; and Matthew H. Hurlock, 'Note. The GATT, US Law and the Environment: A Proposal to Amend the GatT in Light of the Tuna/Dolphin Decision' (1992) 92 Columbia Law Journal 2098 , fn. 171 .

89 Martin Kohr, 'The GatT and Environmental Protection' (1990) Greenpeace 14, 15; Virginia I. Postrel, 'The Big Green Trade-Killing Machine', Wall Street Journal, Sep. 21, 1990, A18; and Patricia Dodwell, 'Trade Row Looms over US Dolphin-Friendly Tuna Policy', Financial Times, Jan. 30, 1992, 22, as quoted in Shoenbaum, 'Free International Trade' (n 12$) 700$.

9o See Esty, Greening the GATT (n 87) 29.

91 William H. Lash III, 'Green Gang's GATt Holdup', Journal of Commerce, Dec. 10, 1993.

92 Esty, Greening the GATT (n 87) 39; David Runnalls and Aaron Cosbey, 'Trade and Sustainable Development. A Survey of the Issues and A New Research Agenda', (1002) IISD Report, 12.

93 Using trade tools to achieve environmental goals was not a new idea. Examples can be found, e.g., in the following conventions: North Pacific Fur Seals Convention, July 7, 1911, 37 Stat. 1542-1543; Convention for the Protection of Migratory Birds, Aug. 16, 1916, 39 Stat. 1702-1704; Plant Protection Convention, Dec. 6, 1951, 15 O U.N.T.s 67; London Convention for the Preservation of Fauna and Flora in Their Natural State, Nov. 8, 1933, 172 L.N.T.S. 254, 256. For an overview of these conventions, see Charnovitz, 'Exploring the Environmental 
the application of such measures as a potential "threat to the trading system and to international harmony more generally," ${ }^{\prime 94}$ reviving the specter of protectionism - the very reason behind international economic cooperation.

However, this was not the first time the collision between industrialized and less developed countries came to the forefront with regards to the adoption of trade restrictions to protect the environment. Their differences vis-à-vis the introduction of the environment issue at the top of the international agenda had already emerged during the Stockholm Conference and in the days spent by several delegations in Founex a few weeks before the Conference commenced. It was precisely in the developing world that the trade elite, moved by the neoliberal ideas that by the early 199os had become the prevailing force behind the trade regime, found a precious ally.

\subsection{Dialogue of the Deaf}

It was comforting to have one place (one might almost say a club) where likeminded people could get together and do their work in peace. ${ }^{95}$ ROBERT E. HUDEC, 1975

A few years into the creation of the GATT, "the administration and incremental development of the trade system was increasingly entrusted to a specialized policy elite insulated from, and not particularly interested in, the larger political and social conflicts of the age." ${ }^{96}$ What had developed in those years has been defined as a trade policy elite, which did not just include some of

Exceptions' (n 61) 42. More recent examples (post-Stockholm) include the following treaties: Convention on International Trade in Endangered Species of Wild Fauna and Flora, Mar. 3, 1973, 993 U.N.T.S.; Montreal Protocol on Substances that Deplete the Ozone Layer, Sept. 16, 1987, 1522 U.N.T.s. 3.; Basel Convention on the Control of Transboundary Movements of Hazardous Wastes and their Disposal, Mar. 22, 1989, 1673 U.N.T.S. 57, 28 I.L.M. 657. Rotterdam Convention on the Prior Informed Consent Procedure for Certain Hazardous Chemicals and Pesticides in International Trade, Sept. 10, 1998, 2244 U.N.T.S. 337; Stockholm Convention on Persistent Organic Pollutants, May 22, 2001, 2256 U.N.T.S. 119; United Nations Framework Convention on Climate Change, May 9, 1992, 1771 U.N.T.S. 107, 31 I.L.M. 849; Convention on Biological Diversity, June 5, 1992, 1760 U.N.T.S. 79; International Tropic Timber Agreement, Jan. 27, 2006, 2797 U.N.T.S. 75 .

94 Esty, Greening the GATT (n 87) 39.

95 Robert E. Hudec, The GATT Legal System and World Trade Diplomacy (Praeger, 1975), p. 57. 96 Howse, 'From Politics to Technocracy' (n 1 ) 98. Howse argues that this lack of interest for the broader political agenda was concurrent with the fact that, with the Cold War, "the high politics of international relations increasingly focused ... on matters of international security and the East-West conflict" and moved away from questions of trade and economic cooperation. 
the officials employed in the GATT Secretariat but, more importantly, a larger group of 'experts' which, although formally outside of the GATT system, in the sense that they never held official positions at the GATT, were, for all purposes, insiders. ${ }^{97}$ Despite their differences in terms of national or personal interests, these insiders formed a network that tended to understand the system in terms of "the policy science of economics [rather than] a grand normative political vision," ${ }^{98}$ as it had been the case in the 1940 .

A network that can be defined, in constructivist terms, as an epistemic community. As aptly explained by Joseph Weiler,

The GATT successfully managed a relative insulation from the 'outside' world of international relations and established among its practitioners a closely-knit environment revolving round a certain set of shared normative values (of free trade) and shared institutional ambitions. GATT operatives became a classical 'network' of first-name contacts and friendly personal relationships. ${ }^{99}$

The environmental community, on the other hand, was considerably more fragmented, often incapable of speaking with just one voice. In Stockholm, for instance, despite the slogan Only One Earth, the press that was covering the Conference used the headline Only 113 Earths to reflect the fragmentation within the community and the vast array of diverging views, in particular between developed and developing countries. As a matter of fact, the Stockholm Conference had revealed that the environment was perceived and valued differently between countries, depending on their different level of environmental sensitivity and awareness as well as their particular stage of economic and social development. ${ }^{100}$ As a result, there were significant differences between the environmental agenda of the North and that of the South.

97 They included, among others, "former or current governmental trade officials, GATTfriendly academics who often sat on GATT/WTO dispute settlement panels and were invited to various conferences and meetings of the GATT/WTO, international civil servants in other organizations preoccupied with trade matters, and a few private attorneys, consultants, and former politicians." Howse, 'From Politics to Technocracy' (n 1) 98.

98 Ibid.

99 Joseph Weiler, 'The Rule of Lawyers and the Ethos of Diplomats: Reflections on the Internal and External Legitimacy of Dispute Settlement', in Roger B. Porter et al. (eds.), Efficiency, Equity, and Legitimacy: The Multilateral Trading System at the Millennium (Brookings Institution Press, 2001), pp. 336-37.

100 Winfried Lang, 'Is the Protection of the Environment a Challenge to the International Trading System?' (1995) 7 Georgetown International Environmental Law Review 463, 473. 
The latter, for instance, was inextricably intertwined with the struggle for social and economic justice and regarded with suspicion the Northern technocratic approach to environmental protection. ${ }^{101}$ Ultimately, the heterogeneity of the members of the environmental community was also reflected in their approach to the trade/environment nexus and, while some environmentalists supported the idea of 'greening the GATT', others did not trust the trade regime to administer any linkage between trade and the environment. ${ }^{102}$

What is more, the trade and environmental communities spoke different languages, relying on entirely different vocabularies, and ended up often 'talking past' one another. ${ }^{103}$ The use of the term 'protection', as pointed out by Daniel Esty, offers a particularly fitting example of the way in which the language used by the two communities could become a source of confusion: "the word 'protection' warm[ed] the heart of environmentalists but sen[t] chills down the spine of free traders." ${ }^{104}$ Another notable example is the word 'dumping', which could reflect two very different concepts, depending on whether one looked at it from a trade or environmental viewpoint: in the trade jargon, it is commonly used to mean the sale of exports below domestic market prices, while in the environmental world it refers to waste being unloaded into rivers, oceans, or soil. ${ }^{105}$

Such differences in the meaning and value attached to certain words had potentially far-reaching effects beyond mere semantics. In fact, the two communities have generally been inclined to approach similar problems in very different ways. ${ }^{106}$ One could think, for instance, of the risks that might derive from permitting regulatory diversity. From a free trade perspective, regulatory diversity exposes the world to the danger that countries will set their environmental regulations and standards 'too high', thereby creating obstacles to the free flow of commerce. Environmentalists, on the other hand, would fear that

101 Carmen G. Gonzalez, 'Beyond Eco-Imperialism: An Environmental Justice Critique of Free Trade' (2001) 78(4) Denver University Law Review 981, 985-6.

102 David W. Leebron, 'Linkages' (2002) 96(1) American Journal of International Law 5, 16.

103 Daniel C. Esty, 'Integrating Trade and Environment Policy Making: First Steps in the North American Free Trade Agreement', in Zaelke et al (eds.), Trade and the Environment (n 11) 47; Peter L. Lallas, Daniel C. Esty, and David J. van Hoogstraten, 'Environmental protection and International Trade: toward Mutually Supportive Rules and Policies' (1992) 16 Harvard Environmental Law Review 271, 274.

104 Esty, 'Integrating Trade and Environment Policy Making' (n 103) 36.

105 Esty, Greening the GATT (n 87) 36.

106 Daniel Magraw, 'Environment and Trade: Talking Across Cultures', Environment, Mar. 19, 1994. 
countries will be tempted to set their regulations and standards 'too low', externalizing harms onto others and ultimately harming the environment. ${ }^{107}$

During the first years of their 'coexistence', the strong divide between the two communities was not limited to differences in language and vocabulary. Rather, it could be better defined as what some scholars have called an actual clash of cultures, encompassing differences in traditions, procedures, and philosophical underpinnings. ${ }^{108}$

The level of openness of the policy-making process is particularly illustrative of these tensions. Public participation and transparency are the keywords characterizing the environmental regulatory system both at the domestic and international level. In the United States, for instance, public participation has always been an essential component of the process through which environmental statutes become law and are later implemented and enforced. ${ }^{109}$ Similarly, in the context of international environmental negotiations, drafts of the agreements are always made accessible to the public and discussed openly. ${ }^{110}$ On the other hand, trade negotiations have traditionally been conducted behind closed doors, in what environmentalists call a 'black box.'11 When a draft of the North American Free Trade Agreement (NAFTA) text, ${ }^{112}$

107 Esty, Greening the GATT (n 87) 44.

108 Ibid., pp. 36-41; Esty, 'Integrating Trade and Environment Policy Making' (n 103) 45, 47; John H. Jackson, 'Greening the Gatт: Trade Rules and Environmental Policy', in James Cameron et al. (eds.), Trade and the Environment: the Search for Balance (Cameron May, 1994), p. 39.

109 The National Environmental Policy Act requires federal agencies to prepare an Environmental Impact Statement for any proposed "legislation [or] major Federal actions significantly affecting the quality of the human environment." The Statement should include, among others, "i) the environmental impact of the proposed action; ii) any adverse environmental effects which cannot be avoided should the proposal be implemented, and iii) alternatives to the proposed action." 42 U.s.c. $§ 4332$ (1988). See McAlpine and LeDonne, 'The United States Government'(n 86) 207.

110 The Brundtland Report of 1987 advised that "At the national level, governments, foundations, and industry should also greatly extend their cooperation with NGO s in planning, monitoring, and evaluating as well as in carrying out projects when they can provide the necessary capabilities on a cost-effective basis. To this end, governments should establish or strengthen procedures for official consultation and more meaningful participation by NGO s in all relevant intergovernmental organizations." World Commission on Environment and Development, Our Common Future (Oxford University Press, 1987) [hereinafter Brundtland Report].

111 See Brian Shoenborn, 'Public Participation in Trade Negotiations: Open Agreements, Openly Arrived At?' (1995) 4 Minnesota Journal of Global Trade 103.

112 North American Free Trade Agreement, US-Can.-Mex, Dec. 17, 1992, 32 I.L.M. 289 (1993) [hereinafter NAFTA]. 
which was being negotiated in complete secrecy, was leaked to the public, the official reaction of the three governments was to deny its accuracy and, even after the agreement was signed, the Bush Administration only agreed to make public a short summary. The complete document was not available until the President left office in 1993, and was sold to the public for the 'reasonable' price of 41 USD. ${ }^{113}$

The openness and transparency of the environmental regulatory system can be explained with the very nature of the object it aims to regulate: the environment. Environmental regulation is often triggered by public demand, and because it imposes positive obligations on governments, it is often essential to mobilize public support for environmental solutions. ${ }^{114}$ On the other hand, according to trade specialists, the secrecy of trade negotiations is required by the competitive nature of world trade, which calls for high levels of confidentiality. ${ }^{115}$ Moreover, the trade system continued to be a 'black box' even after negotiations were successfully completed: the settlement of disputes, for instance, was once again conducted behind closed doors, and non-governmental organizations ( $\mathrm{NGOS}$ ), which are among the main actors inhabiting the environmental world, were not 'welcome' in the proceedings. ${ }^{116}$

At a deeper level, the trade community that had formed during the 1970 s and 1980s was largely driven by economic principles, such as efficiency and comparative advantage, while environmentalists share a law-based worldview. As a matter of fact, economists tend to approach any trade-environment issue as a matter of weighing the relative costs and benefits of trade and environmental policies in maximizing social welfare, starting from the premise that "trade increases income and therefore the capacity to be environmentally conscientious." ${ }^{117}$ Moreover, free traders rely on a narrow definition of economics, including only those factors that are readily quantifiable, while environmental problems are generally not, ${ }^{118}$ leading them to ignore environmental variables

113 Goldman, 'Resolving the Trade and Environment Debate'(n 13) 1283. Ralph Nader and Lori Wallach, 'GATT, NAFTA, and the Subversion of the Democratic Process', in Jerry Mander and Edward Goldsmith (eds.), The Case Against the Global Economy: and for a Turn Toward the Local 92-107 (Sierra Club Books, 1996).

114 Goldman, 'Resolving the Trade and Environment Debate'(n 13) 1282-3.

115 See McAlpine and LeDonne, 'The United States Government'(n 86) 210-11.

116 The reluctance to involve NGO s can be due to the fact that the GATT's structure reflects the international order as it was right after the World War II, when nation-states were the only actors involved. See Esty, Greening the GATT (n 87) 27.

117 Runnals and Cosbey, 'Trade and Sustainable Development' (n 92) 18.

118 As very clearly explained by Esty, "ecological problems are characterized by threshold effects; time lags between emissions and detection; biological, chemical, and physical interactions that are not well understood; and sometimes substantial scientific 
in their analyses: "if you can't put a number on it, leave it out of the equation." Finally, trade specialists have the habit of thinking in terms of products, while environmentalists have always been more concerned with processes, how a good is made, as that is the most relevant stage from an environmental standpoint. ${ }^{119}$

\subsection{Everyone for Themselves}

By behaving like a 'black box', the trade community reflected the 'club model' of multilateral cooperation, where each club is responsible for a specific 'issuearea' and is able to keep outsiders out. The result was the almost absolute lack of opportunities for the two communities to interact and resolve their differences. Rather, this reciprocal isolation did nothing but exacerbate the aforementioned clash of cultures, contributing to the stratification of trade norms oblivious to their environmental repercussions. As the US-Canadian experience of the late 1980 s is particularly illustrative of this clinical isolation, let us consider two events that took place only a few months apart in Toronto and Washington D.C.

On June 27, 1988, over 300 academics, policymakers, scientists, corporate and environmental leaders from 48 countries gathered in Toronto. They had all been invited to participate in the World Conference on the Changing Atmosphere, chaired by Stephen Lewis, Canada's Ambassador to the United Nations, and co-sponsored by the United Nations Environment Programme (UNEP). The Conference coincided with the worldwide occurrence of sudden extreme weather events-from heat waves in Central Europe, to floods in Africa, and droughts in the Midwestern corn belt of the United States ${ }^{120}$ - and was driven by the resulting increased attention devoted to the scientific and social implications of climate change. ${ }^{121}$

Despite the sensitive topic and the difficulties in reaching a consensus on almost every issue that was put on the table, the final plenary session was able to agree on a Conference statement that was "strong, direct, explicit, and

uncertainties over the source, scope, and magnitude of public health or habitat damage." Esty, Greening the GATT (n 87) 40.

119 Robert W. Jerome, 'Traders and Environmentalists', Journal of Commerce, Dec. 27, 1991, 4A.

120 Peter Usher, 'World Conference on the Changing Atmosphere: Implications for Global Security' (1989) Environment, Science and Policy for Sustainable Development, 25.

121 The topics covered during the Conference were, however, not limited to climate change but also included the protection of the ozone layer, long-range transport of atmospheric pollutants, and acid deposition. 1988 was also the year that saw the creation of the Intergovernmental Panel on Climate Change (IPCC) as a joint effort of the United Nations Environment Programme and the World Meteorological Organization. 
readable."122 One of the more startling recommendations contained in the statement called for a 20 per cent cutback on global carbon dioxide $\left(\mathrm{CO}_{2}\right)$ emissions from current levels by 2005, a reduction which could be achieved through increased energy efficiency, reduced energy consumption, and a shift towards low $\mathrm{CO}_{2}$-emmiting fuels. These actions were considered to be necessary given that, as solemnly declared by Norway's Prime Minister Gro Harlem Brundtland in her opening statement, "the impact of climate change may be greater and more drastic than any challenges mankind has faced with the exception of nuclear war."123

Only a few months later, on September 9, then US President Ronald Reagan ratified the United States-Canada Free Trade Agreement, describing it as "an economic constitution for North America." ${ }^{124}$ Unfortunately, this new constitution contained several provisions that were fundamentally at odds with the recommendations penned at the Toronto Conference in June. An entire chapter of the agreement was devoted to the relaxation of regulatory controls to encourage greater energy development and trade, ${ }^{125}$ while at the same time shielding subsidies in the oil and gas sector from attacks under the trade protection laws of either country, by providing them with a special status which was by no means extended to subsidies intended to encourage energy efficiency and conservation. ${ }^{126}$

These contradictions were the result of economic and environmental policy objectives having been pursued, for about 20 years, on entirely separate tracks. Trade and environmental policy-makers had been working in clinical isolation, unaware of the potential synergies between economic and environmental policy objectives. When confronted with the obvious contradictions between the new provisions of USCFTA and the need to actively protect the environment, the Canadian government objected that the former was "a commercial accord

122 F. Kenneth Hare, 'World Conference on the Changing Atmosphere: Implications for Security, held at the Toronto Convention Centre, Toronto, Ontario, Canada, during 27-30 June 1988' (1988) 15(3) Environmental Conservation, 282.

123 Excerpt from Prime Minster Brundtland's opening statement, quoted in 'Toronto Climate Conference Calls for Sharp Cuts in Carbon Dioxide Emissions' (1988) 1(3) Climate Alert 9.

124 United States-Canada Free Trade Agreement, 27 I.L.M. 281 (1988) [hereinafter USCFTA]. 125 Article 904 of USCFTA explicitly prevented either government from restricting the export of energy resources for any other than "national security" reasons, unless supplies are rationed to the same extent domestically.

126 Article 9o6 provides: "Both parties have agreed to allow existing or future incentives for oil and gas exploration, development and related activities in order to maintain the reserve bases for future energy resources." The only other category of government subsidy that is accorded this special status is defense spending. See Shrybman, 'International Trade and the Environment' (n 26) 95, 97. 
between the world's two largest trading partners. It [was] not an environmental agreement ... [and] the environment was not, therefore, a subject for negotiations." ${ }^{127}$ The very same spirit animated the first years of the NAFTA negotiations, with the Bush administration refusing to acknowledge the link between trade and the environment. ${ }^{128}$ US Trade Representative Carla Hills-who only a few years later would proudly define NAFTA the "greenest trade agreement ever negotiated"129_ vocally argued that environmental issues had absolutely no place in trade agreements. ${ }^{130}$

Along the same lines, despite representatives of several countries declared the importance of tackling the 'environment issue' as part of the ongoing multilateral trade talks, ${ }^{131}$ their requests remained largely unanswered and the environment ended up being completely left out of the 1986-1993 GATT negotiations. Once talks had begun, the doors of the Uruguay Round were closed shut, leaving the environmental community out in the cold, as environmental organizations were neither being consulted nor given the opportunity to participate or comment. ${ }^{132}$ As a result, it was the sole prerogative of a few thousand "gold-card-carrying members" of the free trade elite to set the agenda for

127 As quoted in Frank Tester, 'Free-Trading the Environment', in Duncan Cameron (ed.), The Free Trade Deal (Lorimer and Company, 1988); and Shrybman, 'Trading Away the Environment' (n 31) 95 .

128 The goal of the NAFTA negotiations was "to achieve economic growth through the gradual elimination of trade barriers over a fifteen-year period and to create a financial environment which encourages investment while fully protecting industrial and intellectual property rights.” James E. Bailey, 'Free Trade and the Environment-Can NAfTA Reconcile the Irreconcilable' (1992) 8 American University Journal of International Law and Policy 839, 843-4. See e.g. 'Oil Exploration, Environment, Immigration Should Not Be in FTA, Mexican Official Says', International Trade Reporter, Oct. 31, 1990, 1637; 'Ustr Reluctance to Debate Social Aspects of Mexico Pact Worries FTA Backers', Inside U.S. Trade, Jan. 4, 1991, 8 .

129 Carla A. Hills, 'The Trade Pact is Our Best Deal', N.Y. Times, Aug. 17, 1993.

130 See John Audley, 'Why Environmentalists Are Angry about the North American Free Trade Agreement', in Zaelke et al (eds.), Trade and the Environment (n 11$) 193$.

131 The Brundtland Report had urged the Uruguay Round to address "the impacts of trading patterns on the environment" and stressed "the need for more effective instruments to integrate environment and development concerns into international trading arrangements."

132 Shrybman, 'International Trade and the Environment' (n 26) 30. For the objectives of the Round, as spelled out in the Punta dl Este Declaration, see GATT, GAtT Activities in 1986 (Geneva, 1987), 16. See James Cameron and Halina Ward, 'The Multilateral Trade Organization: A Revised Perspective', in Cameron et al. (eds.), Trade and the Environment (n 108) 99. 
the multilateral efforts to expand global commerce in such diverse areas as service, agriculture, and intellectual property rights. ${ }^{133}$

\subsection{Between Two Fires}

The insisting requests to integrate the 'environment issue' in the Uruguay Round negotiations agenda came almost solely from a handful of developed countries, led by the United States. The US had been the motivating force behind the drafting of the NAFTA's environmental side agreement, enacted a few years prior to the conclusion of the Uruguay Round, ${ }^{134}$ and continued exercising its economic and political leverage to ensure the treatment of environmental matters by GATT negotiators. Two congressional proposals had been advanced to this end in the House of Representative. One of them even led to the passing of a resolution which called "upon the President to initiate and complete negotiations, as part of the current Uruguay Round GATT talk" to make the GATT compatible with a number of US health and environmental laws. ${ }^{135}$

Halfway through the Uruguay Round, similar requests were made by the representatives of several other developed countries. Switzerland, speaking on behalf of the members of the European Free Trade Association (EFTA), declared that there was an urgent need to gain a better understanding on the subject of environmental policies and GATT rules. Similar calls came from Sweden, Austria, the EU, as well as Association of South-East Asian Nations (ASEAN) countries. ${ }^{136}$ The EU, for its part, had already extensively incorporated environmental protection into its trade policies, to the point of becoming "a model for the rest of the international community" 137 and brought this disposition to the multilateral trade negotiations in Punta del Este as well.

These requests, however, were opposed by a coalition of developing countries, who expressed vehement opposition to measures designed to link trade

133 Lenora Todaro, 'Attack of the Killer Kapitalists', The Village Voice, Nov. 30, 1999.

134 Daniel P. Blank, 'Target-Based Environmental Trade Measures: A Proposal for the New wTо Committee on Trade and Environment' (1996) 15 Stanford Environmental Law Journal 61,78 . For a detailed account of the role played by the US in this context, see Richard H. Steinberg, 'Trade-Environment Negotiations in the EU, NAFTA, and wTo: Regional Trajectories of Rule Development' (1997) 91 American Journal of International Law 231, 245-9.

135 See H. R. Con. Res. 246, 102d Cong. (1st Sess. 1991), Sec. 1, and Pub. L. 102-582, 106 Stat. 490o, Sec. 203 (1992).

136 See GATT, GATT Activities in 1990 (Geneva, 1991), 16.

137 Philippe Sands, 'European Community Environmental Law' (1991) 100 Yale Law Journal 2511. 
and environmental protection, fearing that such measures would be used by developed countries to block imports of their products. ${ }^{138}$ Along the same lines, during the final sessions of the Uruguay Round, when the role and mandate of the 'Group on Environmental Measures and International Trade' (EMIT Group) was being discussed, delegations from developing countries fought against transforming the Group into a more permanent mechanism to avoid giving the environment a permanent place within the new Organization, arguing that it was a 'trade' organization after all, and fearing that mainstreaming environmental discussions in the newly-established wTо might be used to limit their development options. ${ }^{139}$ These countries were able to keep this position during the first years of life of the พто as well, up until the latestand largely unsuccessful—Doha Round.

Developing countries, who for years had been following the debate with some suspicion from the sideline, had a major interest in defending the integrity of the multilateral trading system, free from environmental or other non-economic considerations, and they finally had the chance to voice their concerns and defend their position. ${ }^{140}$ While in the past richer, larger economies had been able to effectively steer the direction of multilateral trade deals, when the Uruguay Round agreements were being negotiated, nearly all of the Group of 77 developing countries were participating as a single negotiating bloc and were finally capable of asserting their interests. As a result, the picture that emerged from the negotiations was starkly different from the traditional model of power politics, with the "greatest commitment to the multilateral trading system coming from the developing world rather than industrialized states," as sharply noted by Peter Sutherland..$^{141}$

138 See William Drozdiak, 'Poor Nations Resist Tougher Trade Rules', Washington Post, Apr. 14, 1994, A2o; see also Jessica Matthews, The Great Greenless GAtт, Washington Post, Apr. 11, 1994, A19. See also Gonzalez, 'Beyond Eco-Imperialism' (n 101) 982, fn. 7 .

139 Rodrigo J. Prudencio and Stewart J. Hudson, 'Suggestions on an Environmental Reform Agenda at the World Trade Organization', Papers presented at the GatT Symposium on Trade, Environment and Sustainable Development, July 28, 1994, 9-14, 10; Gregory C. Shaffer, "The World Trade Organization under Challenge: Democracy and the Law and Politics of the WTO's Treatment of Trade and Environment Matters' (2001) 25 Harvard Environmental Law Review 1, 23; and Esty, Greening the GATT, (n 87) 37.

140 See Piritta Sorsa, 'GATt and the Environment: Basic Issues and Some Developing Country Concerns', in Patrick Low (ed.), World Bank Discussion Papers: International Trade And The Environment 325 (1992), p. 326.

141 Quoted in Bartram Brown, 'Developing Countries in the International Trade Order' (1994) 14 Northern Illinois University Law Review 347, fn. 223. 
Both free traders and representatives from developing countries saw the GATT as the "guardian of the international trading system,"142 which risked being challenged by environmental considerations, and the environmental community found itself between the proverbial two fires. Even after the Uruguay Round was completed, a large part of the trade community, with the support of less developed countries, kept arguing that environmental issues were best kept out of the trade policy-making process. ${ }^{143}$ In 1999, Jagdish Bhagwati drafted a statement, signed by 99 intellectuals and NGO s from the Third World, asking the wTо, and trade negotiators more broadly, to 'bury' the "linkage of labor and environmental standards to WTо and to trade treaties." ${ }^{144}$ In their view, the 'moral face' of the countries supporting this linkage was nothing more than "a mask which [hid] the true face of protectionism."145 They argued that by allowing such linkage, the real goal of the WTO-trade liberalization-would be harmed, as linking non-trade issues "undermines both the freeing of trade and the advancing of our social agendas"146 because one instrument (wTO rules) cannot be used to achieve two targets:

The underlying reason for such an unsatisfactory outcome is that you are trying to kill two birds with one stone. Generally, you cannot. So, trying to implement two objectives, the freeing of trade and advancing social and moral agendas, through one policy instrument such as WTO, you will undermine both. You will miss both birds. ${ }^{147}$

The very same view had been expressed, a few years prior, by Indian Prime Minister Pranab Mukherjee who, voicing the concerns of many developing countries and vowing to fight the inclusion of any social or environmental clause in multilateral trade rules, stated that he saw "no merit whatsoever in the attempt to force linkages where they do not exist; trade policy cannot be made the arbiter of all concerns."148

\footnotetext{
142 Sorsa, 'GATT and the Environment' (n 140) 339.

143 Daniel C. Esty, 'Bridging the Trade-Environment Divide' (2001) 15(3) Journal of Economic Perspectives 113 .

144 Jagdish Bhagwati, 'Third World Intellectuals and NGos Statement Against Linkage (TWINS-SAL)', 1999.

145 Ibid.

146 Jagdish Bhagwati, 'On Thinking Clearly About the Linkage Between Trade and the Environment' (2000) 5 Environment \& Development Economics 483, 494.

147 Bhagwati, 'Third World Intellectuals' (n 144).

148 Quoted in Drozdiak, 'Poor Nations Resist Tougher Trade Rules' (n 138).
} 


\subsection{Development First}

Seemingly overnight, the environment issue - and the question of its role and place vis-à-vis international trade norms and policies-saw the development and the free-trade agendas standing next to each other on the same side of the barricade, adding a North-South dimension to the already clear free trade v. environment dichotomy. Indeed, "environmental diplomacy is often said to run along the lines of the North-South divide, with opposite positions being advocated by the developed world versus the developing countries." 149 This divide had already emerged loud and clear in 1972 in Stockholm, as evidenced by Maurice Strong's strenuous efforts to ensure developing countries' participation in the Conference.

In truth, the international development movement has much older roots when compared to the environmental one. Grown out of the decolonization process following World War II and anchored in the recognition that newlyindependent developing nations were justified to aspire to the same level of economic and social development of their industrialized counterparts, by the 196os, the development movement had become one of the most prominent forces in global relations. ${ }^{150}$ In September 1961, almost a year before Nixon declared that the 1970 s would be 'the environmental decade', John F. Kennedy had launched a proposal for making the 196os the 'UN Development Decade.' This proposal was followed by an increasing engagement of the international community with the issue of development, through a variety of actions both within and outside of the UN. Within the UN, in particular, different institutions were created to deal with different facets of the issue, such as the United Nations Conference on Trade and Development (UNCTAD), established in 1964 and, the following year, the United Nations Development Program (UNDP).

When the Stockholm Conference was convened, all the efforts and energy of the developing world were devoted to the goal of development, while terms like 'environmental degradation' and 'environmental quality' seemed like luxurious preoccupations and had an abstract ring about them to societies whose immediate concerns were food, housing, employment, medical care, and education. ${ }^{151}$ Unlike industrialized nations, where a growing number of

149 Gaetan Verhoosel, 'Beyond the Unsustainable Rhetoric of Sustainable Development: Transferring Environmentally Sound Technologies' (1998) 11 Georgetown International Environmental Law Review 49.

150 Claire Brighton, 'Unlikely Bedfellows: The Evolution of the Relationship between Environmental Protection and Development' (2017) 66 International and Comparative Law Quarterly 209, 213.

151 J. Lee, 'Environmental Considerations in Project Appraisal, United Nations Conference on the Human Environment', Panel of Experts on Development and Environment, Working 
environmental, health, conservation, and consumer advocates were being vocal about emerging environment problems, large segments of the public opinion in developing countries regarded the consideration and discussion of these problems with suspicion and even hostility. ${ }^{152}$ Thy feared that such 'obsessive' concern with problems of the environment might "divert national and international attention from the urgent problems of the economic and social development of the underdeveloped world" or even undermine their industrialization process. ${ }^{153}$

Developing countries' claim to a 'right' to industrialize stood in stark contrast with the kind of environmental problems developed nations denounced in Stockholm: many of these problems were occurring precisely as a result of the same industrialization processes that had produced "such unparalleled levels of wealth and prosperity" in the industrialized world. ${ }^{154}$ Just like developed nations did a few centuries ago, developing countries should now be free to build their industries as they wish, pollution or not.

There is no denying that environmental protection was felt as an important issue in the developing world as well. However, the environmental agenda of the North and that of the South differed greatly. The latter, in particular, was inextricably intertwined with the struggle for social and economic justice, which was instead completely neglected by Northern environmentalists. ${ }^{155}$ The meeting organized in Founex, Switzerland, a few weeks before the Stockholm Conference, was designed precisely to mediate these diverging, and seemingly irreconcilable views. One of the views that emerged from Founex was the causative link between underdevelopment and environmental degradation: although it was indeed true that developing countries were not unconcerned with environmental problems, it was also true that the major problems they were facing were different from those characterizing industrialized nations, as they mostly reflected poverty and lack of development and, rather

Paper No. 7 (4 June 1971) (on file with the Environmental Science and Public Policy Archives at Harvard University, Maurice F. Strong Papers, Box 40[396]), 3.

152 Lori Wallach, 'Hidden Dangers of GATT and NAFTA' (n 35) 26-7. Enrique Iglesias, 'Development and the Human Environment', United Nations Conference on the Human Environment, Panel of Experts on Development and Environment, Working Paper No. 1 (June 4, 1971), para. 20.

153 Iglesias, Development and the Human Environment (n 152) para. 19.

154 Maurice F. Strong, 'ECO'92: Critical Challenges and Global Solutions' (1991) 44Journal of International Affairs 287 .

155 Gonzalez, 'Beyond Eco-Imperialism' (n 101) 985-6. 
than being the result of the development process, could be overcome by the process of development itself. 156

Brazil's Ambassador Miguel Ozorio De Almeida, one of the driving forces behind developing countries' positions in Stockholm, called for the Conference to become an "economic development conference,"157 to be able to tackle effectively the South's environmental concerns. On the other side, some delegates, including Maurice Strong himself, stressed the need to ensure that the Conference not "become another UNCTAD,"158 emphasizing that development objectives should not be allowed to "flood out any serious consideration of the questions of pollution and other uses of natural resources which were ... the original purpose of the Conference."159 Despite the seeming 'victory' of the North, with the Conference being centered around the 'human environment' (rather than development, at it would be the case 20 years later in Rio), Founex ended up introducing a claim to prioritization: environmental policies that reinforced economic growth in the global South would be more readily accepted and supported compared to those conflicting with economic growth, for example by hampering trade..$^{160}$

As a result, those environmental considerations that resulted in new, tighter regulation and control in industrialized countries were seen as operating to developing countries' disadvantage. ${ }^{161}$ Let us take the example of tuna, which led environmentalists to take to the streets and wave banners in Washington D.C. in the Spring of 1992. More often than not, tuna harvested in developing and least-developed countries was found to have higher levels of contamination than those established in the US as maximum levels, and was fished with techniques that were often far from being environmentally safe. ${ }^{162}$ Limiting trade to tuna fished respecting US levels would have meant the cutting off of

\footnotetext{
156 Founex Report on Development and Environment (1971).

157 Miguel A. Ozorio de Almeida, 'The Confrontation Between Problems of Development and Environment' (1970-1) 39 International Conciliation 37, 53.

158 Note of Conversation with Mr. Maurice Strong on 11 February 1971, Geneva, attached to Letter from R. Arculus, 9 Feb 1971 to Mr. Ure, 'Preparatory Committee for the UN Conference of the Human Environment: Second Session: Geneva—8 to 19 February 1971', United Kingdom National Archives, Folder FCO 55/670.

159 Letter DM Kitching to Mr. Williams and Mr. Mathieson (first initials not given), UK Foreign and Commonwealth Office, 24 September 1971, United Kingdom National Archives, folder FCO55/672.

16o Brighton, 'Unlikely Bedfellows (n 150) 214.

161 Maurice Strong's interview for the Canadian Broadcasting Corporation on 'Limits to Growth' (Mar. 1975) (on file with the Environmental Science and Public Policy Archives at Harvard University, Maurice F. Strong Papers, Box 27[268]), 26.

162 Ibid.
} 
a major market for some Asian countries. ${ }^{163}$ It then should be no surprise that the first generation of trade/environment disputes often opposed developed and less developed countries, the former defending a certain environmental measure and the latter challenging it because it was trade-restrictive and ultimately affecting their economies and industries. ${ }^{164}$

\subsection{To Each His Own Fear}

The Tuna/Dolphin case marked the beginning of an intense international debate on the legitimacy and legality of unilateral trade measures to protect the environment. Some countries, however, had been using trade sanctions to compel other nations to implement environmental measures for nearly two decades. ${ }^{165}$ The most well-known example of a national statute authorizing the adoption of such 'environmental' trade sanctions is probably the 1971 Pelly Amendment to the US Fishermen' Protective Act of 1967.166 The famous amendment, named after Thomas M. Pelly, the Congressman who proposed it at the very end of his long career in the US House of Representatives, was introduced in response to Denmark, Norway, and West Germany's refusal to ban high salmon fishing. The ban, which had been established in 1969 by the International Commission for the Northwest Atlantic Fisheries (ICNAF) to conserve fishing resources in the area, was presented in a manner that allowed countries to ignore it without technically violating the terms of the ICNAF. ${ }^{167}$ This represents a clear example of a situation where, despite being preferable, multilateral consensus is often difficult to achieve and unilateral action might present itself as the better option from an environmental standpoint. As a matter of fact, the three countries' refusal to comply with the ban "effectively nullified any benefits that would come"168 from it, thus motivating the US Congress to vote for Pelly's proposal. As ultimately drafted, the Amendment authorized the President to prohibit the importation of any product from a foreign country whose nationals conducted fishing operations that diminished

\footnotetext{
163 Ibid.

164 See US - Tuna I (complainant: Mexico); US_Gasoline (complainant: Venezuela and Brazil); US —Shrimps (Complainant: India, Malaysia, Pakistan, and Thailand). This of course was not always the case and several disputes have been registered during the same years where developed countries acted both as complainants and respondents.

165 Gonzalez, 'Beyond Eco-Imperialism' (n 101) 1004.

16622 U.S.C. $\$ \$ 1971$ et seq.

167 Gene S. Martin and James W. Brennan, 'Enforcing the International Convention for the Regulation of Whaling: The Pelly and Packwood-Magnuson Amendments' (1989) 17 Denver Journal of International Law \& Policy 293, 294.

168 Ibid., 295.
} 
"the effectiveness of an international fishery conservation program" or engaged in trade that diminished "the effectiveness of any international program for endangered or threatened species." 169

In 1992, the Pelly Amendment was revised to expand the range of products against which a US President could invoke countermeasures and, two years later, President Bill Clinton relied on it to impose a ban on all wildlife products from Taiwan to stop the sale of rhinoceros horns and tiger bones which were undermining the 1973 Convention on International Trade in Endangered Species of Wild Fauna and Flora (CITES). ${ }^{170}$ Environmentalists in developed countries immediately applauded the sanctions against Taiwan "as one of the top five environmental successes of 1994," recognizing them as an extremely effective tool "in helping curb the deadly commerce in endangered species. ${ }^{\prime 171}$ Others, on the other hand, harshly criticized the sanctions as entirely oblivious to the specific interests of developing countries and as a means of simply imposing American values on Taiwan's culture. ${ }^{172}$ For the exact same reasons, several Southeast Asian governments and their allies in the developing world had challenged, in a session of the GATT Council, the legality of an Austrian law which prescribed 'ecolabelling' for imported tropical timber and timber products. ${ }^{173}$

These events, which ultimately culminated in the Tuna-Dolphin controversy, reflected a conflict with respect to the use of unilateral 'environmental' trade sanctions between free trade and environmental protection, and between Northern environmentalists and developing countries. This conflict has often been described as one between 'high-level' and 'low-level' countries to stress that the opposing views pit countries with high environmental standards against those with lower ones. ${ }^{174}$

16922 U.s.C. $§ 1978(a)(1)-(2)$ (1988 \& Supp. IV 1992), as quoted in Howard F. Chang, 'An Economic Analysis of Trade Measures to Protect the Global Environment' (1995) 83 Georgetown Law Journal 2131, 2137.

170 The ban was lifted less than year after it was imposed, after Taiwan adopted critical measures to halt commercial trade in rhinocero horns and tiger bones. See Blank, 'TargetBased Environmental Trade Measures' (n 134) 62-3.

171 'The Best Environment of 1994', Time, Dec. 26, 1994, 144; Press Release from the World Wildlife Fund, World Wildlife Fund Statement on US Government Decision to Lift Pelly Amendment Sanctions Against Taiwan (June 30, 1995) (on file with the Stanford Environmental Law Journal).

172 James Sheehan, 'Most Favored Fauna Treatment', Washington Times, May 31, 1994, at A12.

173 GatT Doc. C/M/26o, 40-56 (Nov. 26, 1992). See Lang, 'Is the Protection of the Environment'(n 100) 465-6.

174 See e.g. Ileana M. Porras, 'The Puzzling Relationship Between Trade and the Environment: NAFTA, Competitiveness and the Pursuit of Environmental Welfare Objectives' (1995) 3 Global Legal Studies Journal 65; Jagdish Bhagwati and T.N. Srinivasan, 
Representatives of the former category justified the legitimacy and legality of their unilateral measures on both economic and environmental grounds. First, differential (and in this case 'lower') environmental practices were seen as conferring 'unfair' trade advantages to low-level countries' producers. Maintaining low environmental standards allowed domestic producers to incur lesser costs and was therefore compared to a subsidy or dumping practice. This position was explained with extreme clarity by US Senator Boren in the context of the adoption of the International Pollution Deterrence Act:

We can no longer stand idly by while some US manufacturers, such as the US carbon and steel alloy industry, spend as much as 250 percent more on environmental controls as a percentage of gross domestic product than do other countries ... I see the unfair advantage enjoyed by other nations exploiting the environment and public health for economic gain when I look at many industries important to my own state of Oklahoma ... ${ }^{175}$

As a consequence, environmentalists in the industrialized world further feared that their own countries would then be forced by political pressure to lower their own environmental protection standards in order to remain competitive. Otherwise, their industries would relocate to low-level countries leading to a snowballing race to the bottom.

Developing countries, for their part, regarded these arguments as mere excuses and continued labelling unilateral sanctions as clear examples of 'green protectionism' and 'eco-imperialism' or, in other words, as developed countries' newly found way to impose their own "pollution control and resource conservation strategies on the South, notwithstanding the South's conflicting environmental preferences, economic preferences, and priorities." ${ }^{\prime 76}$ Ultimately, developing countries saw restricting trade on grounds of differences in environmental standards as the pure and simple imposition of values by importers upon exporters, as an expression of disapproval of a country's environmental behavior by forcing compliance with more acceptable standards. The underlying question is: "acceptable according to whom?" Or, in other words, what can

'Trade and the Environment: Does Environmental Diversity Detract from the Case for Free Trade?' Discussion paper Series No. 718 (January 1995).

175 International Pollution Deterrence Act of 1991. Statement of Senator David L. Boren, Senate Finance Committee, October 25, 1991.

176 Esty, Greening the GATT (n 87) 181-192. See e.g. Bill L. Long, 'Identifying Environmental Options in Development' (January 1972). Development Digest Vol. IX No. 1. 
be considered an 'acceptable' level of pollution or environmental degradation and who gets to decide?

What developed countries saw as an unfair trade advantage, developing countries guarded as a fundamental expression of their own sovereignty over resource management and pollution control decisions. And while developed countries saw the adoption of sanctions as an effective way to level the playing field', the developing world regarded them as the unjustified imposition of Northern ethical preferences to countries characterized by a different level of environmental awareness, a different stage of economic and social development, as well as different endowments in financial and technological resources.

\subsection{Like Riding Bicycles}

This perspective on trade and environment was shared by both developing countries and free traders, albeit with different emphases. ${ }^{177}$ Developing countries based their arguments on their sovereign right to formulate their own environmental goals, while free trade economists and advocates praised differential standards across nations as they determine a nation's comparative advantages, on which trade rules are based to increase welfare. ${ }^{178}$

The many challenges the 'environment issue' had to face once introduced on the international agenda, and in its relationship with trade in particular, were somehow exacerbated and crystallized by the predominance of the neoliberal economic thought. The latter framed the trading system as being "for free trade and free markets, and against governmental interference,"179 while all forms of government intervention, even when they pursued legitimate policy goals, were regarded with suspicion as potential protectionism in disguise.

In line with neoliberal economic thinking, in the 1999 statement signed by Third World Intellectuals, Bhagwati identified trade liberalization as the "true objective" of the multilateral trading system. ${ }^{180}$ By reading the Preamble to the GATT, however, one can gather that trade liberalization, rather than being the goal of the agreement, is just a means serving broader goals, namely "raising standards of living, ensuring full employment and a large and steadily growing volume of real income and effective demand, developing the full use of the resources of the world and expanding the production and exchange of

177 Saunders, 'Trade and Environment'(n 10) 726.

178 Robert E. Hudec, 'Differences in National Environmental Standards: The Level-PlayingField Dimension' (1996) 5o Minnesota Journal of Global Trade 1, 22.

179 Lang, World Trade Law After Neoliberalism (n 3 ) 4.

180 Bhagwati, 'Third World Intellectuals' (n 144). 
goods." ${ }^{181}$ To achieve these objectives, the drafters identified two-necessary but not sufficient-means, namely the substantial reduction of tariffs and other barriers to trade, and the elimination of discriminatory treatment in international commerce. ${ }^{182}$

As the 1999 statement shows, however, members of the trade community, and economists in particular, can sometimes "lose sight of these goals by narrowing the operational goal of trade agreements to that of trade liberalization."183 This narrow understanding of the goal of the trade regime can be explained with the strong influence of the 'bicycle theory' of trade liberalization on the trade community, according to which an open trading system will be maintained only if forward momentum for trade liberalization continues to avoid that the bicycle might fall over. ${ }^{184}$

After the 'environment issue' emerged in the early 1970s, the major constant goal of the GATT, and any other bilateral or regional trade agreement, remained the "establishment and preservation of an open world trading system,"185 and whenever trade specialists were required to address subjects that today would be subsumed under the environmental label, they would do so keeping both eyes on their ultimate- economic - goal. When, for instance, the issue of natural resources and natural resource-derived products was raised during the Uruguay Round, the discussion, far from addressing the need to protect natural resources, revolved around a proposal to remove trade barriers to their free flow, which, if successful, would have led to higher demand and unsustainable resource management, ${ }^{186}$ rather than conservation—as advocated by environmentalists.

Along the very same lines, when the US adopted a measure based on the Marine Mammal Protection Act (MMPA) of $1972^{187}$ prohibiting the import of foreign tuna caught with commercial fishing technology which resulted in the

181 GatT, Preamble. The language of the GatT preamble was inspired by Point 5 of the Atlantic Charter, which read: "Fifth, they desire to bring about the fullest collaboration between all nations in the economic field with the object of securing, for all, improved labor standards, economic advancement and social security."

182 See Victoria Curzon, 'The Management of Trade Relations in the GatT', in Andrew Shonfield (ed.), International Economic Relations of the Western World 1959-1971, Vol. I 143-283 (Oxford University Press, 1976), p. 147.

183 Gregory Shaffer, 'Retooling Trade Agreements for Social Inclusion' (2019) 1 University of Illinois Law Review 1, 5 .

184 Fred Bergsten, Toward a New International Economic Order (Lexington Books, 1975).

185 GATT, GATT Activities 1980 (Geneva, 1981). The reports of GATT Activities until 199o do not touch upon the environment issue either.

186 See Housman and Zaelke, 'Trade, Environment, and Sustainable Development'(n 12$) 562$.

187 Marine Mammal Protection Act, 16 U.s.c. $§ 1361-1423$ h (1972) [hereinafter MMPA]. 
incidental killing or serious injury of dolphins, a GATT panel declared the measure inconsistent with trade rules. Just like the GATT negotiators who faced the 'natural resources issue', the panel, composed of members of the very same trade community, concluded that trade restrictions in response to other countries' lower environmental practices were per se inconsistent with the GATT. ${ }^{188}$ As argued by Howse, this ruling was "without textual basis in GATT law" but was rather based "on some intuitive notion that allowing trade measures to address global environmental externalities was somehow countenancing a slippery slope towards unconstrained green protectionism" and therefore risked undermining the trade liberalization goal of the GATT itself. ${ }^{189}$ While the trade community welcomed the decision with praise, environmentalists strongly criticized it — and the GATT in general — for its environmental insensitivity: "the panel's rulings may be legally sound" read the Washington Post only a few days after the decision was made public "but they are environmental nonsense." 190

The environment had found itself at a great disadvantage: not only had it emerged on the international political agenda later than other-economic and developmental-concerns, but it also found itself at the mercy of the prevailing neoliberal doctrine, which inspired the trade community, and of the suspicions and hostilities of the developing world. Not only had the environment been cornered into exception clauses, but, as addressed in the following paragraphs, the neoliberal turn taken by the trade regime contributed to a strict and narrow interpretation of such exception clauses vis-à-vis the protection of the environment. This strictness, once again, was not part of the GATT founders' original grand vision.

\section{How Exceptions Work: The Environment Upstaged}

According to the GATT Report on Industrial Pollution Control and International Trade of 1971, national standards to address pollution concerns "are already

188 Report of the GATT Panel, US - Tuna I, paras 5.27, 5.32, and 6.2.

189 Robert Howse, 'The World Trade Organization 20 Years On: Global Governance by Judiciary' (2016) 27(1) European Journal of International Law 9, 36-7.

190 The article continues: "No country can protect its own smidgen of air or ocean or living part of the global commons. Trade measures are often the only means short of a multilateral treaty to influence the behavior of other countries." See Jessica Matthews, 'Dolphins, Tuna and Free Trade', Washington Post, Oct. 18, 1991, A21, as quoted in Hurlock, 'Note' (n 88) 2131. 
covered in a general way in GATT, especially through exceptions in Article $\mathrm{xx}$, permitting imposition of restrictions on goods harmful to public health and safety."191 In other words, in the view of trade officials, trade law already addressed the concerns of environmentalists by providing, through the exceptions in Article Xx, the necessary leeway for countries to adopt domestic environmental regulations.

Exception clauses were introduced in the text of the GATT by its founders, right next to the principles of non-discrimination and tariff reduction, to combine trade liberalization with the assurance that countries would be able to pursue a variety of social policies. As the trade community came to be characterized, after the 1970s, by a "crude economist ideology and strong deregulatory orientation," 192 not only was Article III given a more expansive interpretation, but Article $\mathrm{xx}$ - the only refuge left to environmental protection - was deprived of its original meaning and it became nearly impossible to justify domestic policies under this clause. As a matter of fact, this approach has done nothing but amplify certain features typical of exception clauses in generalwidely used in international law — which already make them hard to rely on: they are generally narrowly defined, strictly interpreted and applied, and whoever invokes them bears the burden of persuasion.

\subsection{A Clause to Prevent All Abuses}

On November 13, 1946, the Preparatory Committee of the International Conference on Trade and Employment (Preparatory Committee) was getting close to completing its first session at Church House, in London. ${ }^{193}$ Committee II, one of the working committees that had been established to divide and speed up the work, was in charge of 'General Commercial Policy', and it was under its aegis that the very first draft GATT articles were prepared. ${ }^{194}$ When the discussion turned to Article 32 of the draft - which later became Article 37 and finally Article $\mathrm{xx}-\mathrm{Mr}$. Cherry, the delegate from South Africa, ${ }^{195}$ called

\footnotetext{
191 GATT, Industrial Pollution Control and International Trade (n 9) 12 (emphasis added).

192 Howse, 'The World Trade Organization 20 Years On' (n 189) 48.

193 The first session of the Preparatory Committee ran from October 15, 1946 to November 20,1946 .

194 The other working committees were: Committee I: Employment and Economic Activity; Committee III:Restrictive Business Practices; Committee IV: Intergovernmental Commodity Arrangements; and Committee v: Administration and Organization. See Douglas A. Irwin, Petros C. Mavroidis, and Alan O. Sykes, The Genesis of the GATT (Cambridge University Press, 2008), p. 107.

195 During this session of Committee II, Delegates of six different nationalities acted as rapporteurs (Belgium, Czechoslovakia, New Zealand, South Africa, UK, and US).
} 
everyone's attention to a delicate issue that had been raised a few weeks prior by the Belgian and Dutch delegates: the issue that, often, the stipulations "to protect animal or plant life or health" are misused for indirect protection. ${ }^{196}$

The risk that these exceptions might lead to abuse had already been observed many years before as "under the guise of biological protection, it is very easy to introduce economic protection." ${ }^{197}$ To avoid such abuses, by the mid-1920s, many treaties started imposing conditions on their exceptions. The Treaty between Japan and Mexico of 1924, for instance, required animal and plant laws and regulations to be "applicable to all countries or to countries in similar circumstances." ${ }^{198}$ However, these conditions, which were then reproduced in several commercial agreements, did not seem adequate or sufficiently clear to the Church House negotiators. ${ }^{199}$ Something else was needed. Something that would shield the provision from any possible future abuse.

After long discussions, Mr. Cherry recommended the insertion of a preambular clause that would prohibit abuse of these exceptions and, in general, the attainment of results that were incompatible with the aim of the Agreement. ${ }^{200}$ To this end, the UK delegate, Mr. Rhydderch, proposed to add the following clause as an introduction to Article 32:

The undertakings in Chapter IV of this Charter relating to import and export restrictions shall not be construed to prevent the adoption or enforcement by any Member of the following measures, provided that they are not applied in such a manner as to constitute a means of arbitrary discrimination between countries where the same conditions prevail, or a disguised restriction on international trade. ${ }^{201}$

196 E/PC/T/C.II/32 (Oct. 3o, 1946), 11. See also E/PC/T/C.II/W.20 (June 11, 1946).

197 Percy W. Bidwell, The Invisible Tariff. A Study of the Control of Imports into the United States (Council on Foreign Relations, 1939), p. 17.

198 Treaty between Japan and Mexico, 36 L.N.T.s. 278 (no longer in force). Another example is provided by the Treaty between Czechoslovakia and Sweden of 1925, which required measures adopted to protect animal or plant life or health to be "in conformity with the universally recognized international regulations" - whatever they might be. See Charnovitz, 'A Taxonomy' (n 12) 41.

199 The phrase "provided that corresponding safeguards are applied in the importing countries if similar conditions exist in that country," which was added to text of Article $\mathrm{xx}(\mathrm{b})$ - then $37(\mathrm{~b})$ - was later removed because considered unclear and inadequate $(\mathrm{E} /$ $\mathrm{PC} / \mathrm{T} / \mathrm{A} / \mathrm{PV} / 3^{\circ}$, at $\left.11-13\right)$. The phrase was first introduced by the Drafting Committee of the Preparatory Committee of the United Nations Conference on Trade and Employment on February 11, 1947 (E/PC/T/C.6/55/Rev.1).

200 E/PC/T/C.II/50 (Nov. 13, 1946), 6.

201 Ibid., 7. 
The UK proposal was welcomed by all the other delegates and, with a few changes, found its way in the New York draft and later in the final version of GATT Article Xx. ${ }^{202}$ The insertion of the chapeau reveals the fears that surrounded this exception clause. It is true that it had been part of trade agreements for more than a century, but its scope had become broader-it originally used to only apply to import prohibitions and restrictions while it now started covering a much wider field ${ }^{203}$ — and it had now become part of a multilateral agreement, with potentially much more far-reaching consequences.

The decision of the GATT drafters to introduce the chapeau was motivated by the intention of framing it as an 'anti-protectionism' norm, applicable against those internal measures that were motivated by protectionist intents. Over time, however, all forms of government intervention in the economy began to be regarded as potentially trade distortive and the importance of distinguishing between legitimate domestic regulation and regulation with protectionist motives was somehow lost. As a result, the chapeau became a shield against all internal measures that had a negative impact on international trade, regardless of the intent behind their adoption. By doing so, it ultimately reiterated the primacy of GATT's main objective vis-à-vis countries' intentions to protect the environment: "[w]hile the exceptions of Article xx may be invoked as a matter of legal right, they should not be so applied as to frustrate or defeat the legal obligations of the holder of the right under the substantive rules of the General Agreement."204 In other words, states can adopt policies, regulations, and standards to protect the environment only as long as they do not constitute (unnecessary) barriers to trade: ${ }^{205}$ this way, the need to protect commerce from undue burdens seemed to effectively override any environmental protection concerns.

202 See E/PC/T/C.6/55 (Feb. 5, 1947); E/PC/T/C.6/55/Rev.1; E/PC/T/142 (Aug. 1, 1947); and E/ $\mathrm{PC} / \mathrm{T} / 154$ (Aug. 6, 1947). Interestingly, a clause similar to the current chapeau of Article XX could already be found in the forefather of this provision, Article 4 of the ${ }_{1927}$ Preliminary Draft for the International Agreement for the Abolition of Import and Export Prohibitions and Restrictions ("The following classes of prohibitions and restrictions are not prohibited by the present Convention, on condition, however, that they are not applied in such a manner as to constitute a means of arbitrary discrimination between foreign countries where the same conditions prevail, or a disguised restriction on international trade.")

203 E/PC/T/C.II/5O, 7 (Remarks of the UK delegate, Mr. Rhydderch).

204 Panel Report, United States - Standards for Reformulated and Conventional Gasoline, WT / DS2/R (May 20, 1996) [hereinafter US—Gasoline], 22.

205 This approach was already clear in both the 1971 and 1992 studies of the GATT Secretariat on the relationship between trade and the environment. 
A very similar approach characterized domestic experiences as well. In the United States, for instance, the existing division of authority between federal and state created very similar obstacles to states enacting laws that are more protective of the environment. The US Supreme Court has interpreted the Commerce Clause's conferral of authority to Congress over interstate commerce to create, by negative implication, a limit on state laws that unduly burden interstate commerce (Dormant Commerce Clause). ${ }^{206}$ States are free to protect the environment - together with other legitimate public interests - within the restraints imposed by the Commerce Clause itself. ${ }^{207}$ These restraints do not appear in the words of the Clause, but have been developed and clarified by the Supreme Court in a long series of decisions, which have reflected "an alertness to the evils of 'economic isolation' and protectionism." 208

According to the interpretation of the Court, while discriminatory restrictions on commerce-regardless of the purpose - are virtually per se invalid, ${ }^{209}$ when a statute "regulates even-handedly to effectuate a legitimate level public interest, and its effects on interstate commerce are only incidental, it will be upheld unless the burden imposed on such commerce is clearly excessive in relation to the putative local benefits." 210 In other words, "no state action can survive a commerce clause analysis if its effect on interstate commerce is heavily burdensome or if it discriminates against interstate commerce."211 While more lenient than the test applied through GATT Article Xx, nevertheless regulation of interstate commerce maintains a privileged position in the constitutional scheme. ${ }^{212}$ Once again, the benchmark to decide whether a measure

206 This prohibition was first recognized in Gibbons v. Ogden, 22 U.S. 1 (1824), 1, 209-11 (1824). On the dormant commerce clause, see generally Martin H. Redish and Shane Nugent, 'The Dormant Commerce Clause and the Constitutional Balance of Federalism' (1987) Duke Law Journal 569 .

207 Philadelphia v. New Jersey, 437 U.S. 617, 623 (1978).

208 Ibid., 623-4.

209 The Court set forth the controlling principle in case of discriminatory measures in Dean Milkv. Madison, 340 U.S. 349 (1951). Here the Court held: "Madison plainly discriminates against interstate commerce. This it cannot do, even in the exercise of the unquestioned power to protect the health and safety of its people, if reasonable non-discriminatory alternatives, adequate to conserve legitimate local interests, are available." 354 .

210 Pike v. Bruce Church, Inc., 397 U.S. 137, 142 (1970) (emphasis added). See also Oregon Waste Sys. v. Environmental Dep't, 511 U.S. 93 (1994).

211 Ira Steven Lefton, 'Constitutional Law-Commerce Clause: Local Discrimination in Environmental Protection Regulation' (1977) 55(2) North Carolina Law Review 461, 465.

212 See C\&A Carbone Inc. v. Town of Clarkstown, 511 U.S. 383 (1994); Oregon Waste Sys. v. Environmental Dep't; Chemical Waste Management, Inc. v. Hunt, 504 U.S. 334 (1992); Fort Gratiot Landfill v. Michigan Dep't of Natural Resources, 504 U.S. 353 (1992); Philadelphia v. New Jersey. 
can survive a commerce clause analysis is its trade restrictiveness, rather than the potentially protectionist motivations behind its adoption.

Very similar language to the one used by the Supreme Court in the majority opinion delivered in its 1970 landmark decision in Pike v. Bruce Church can be found in the Guiding Principles Concerning the Economic Aspects of Environmental Policy adopted by the Council of the Organization for Economic Cooperation and Development (OECD) on May 26, 1972:

Measures taken to protect the environment should be framed as far as possible in such a manner as to avoid the creation of non-tariff barriers to trade ... In conformity with the provisions of the GATT, measures taken within an environmental policy should be applied in accordance with the principle of national treatment and with the principle of non-discrimination. ${ }^{213}$

Similarly, the Action Plan adopted in Stockholm in the very same year clarified that environmental concerns should not be used as a pretext or as an excuse to violate the trade rules agreed on in Havana: according to Recommendation 103, for instance, "it is recommended that Governments take the necessary steps to ensure: (a) That all States participating in the Conference agree not to invoke environmental concerns as a pretext for discriminatory trade policies or for reduced access to markets ..."214

Along the same lines, both 1990s Tuna/Dolphin panels gave significant weight in their decisions to the fact that permitting the challenged US measure would in their view radically jeopardize the Parties' rights under the GATT, which would "no longer constitute a multilateral framework for trade among all contracting parties but would provide legal security only in respect of

213 The extract continues: "[environmental policies] should not be accompanied by subsidies that would create significant distortions in international trade and investment ... Governments should seek harmonization of environmental policies ... to avoid the unjustified disruption of international trade patterns and of the international allocation of resources which may arise from diversity of national environmental standards ..." Taken from Maurice F. Strong, Address as the Southwestern Economic Association Meetings, Dallas: Economic Development and International Response to Environmental Decay (Mar. 23, 1973) (on file with the Environmental Science and Public Policy Archives at Harvard University, Maurice F. Strong Papers, Box 28[287]).

214 Stockholm Action Plan, Recommendation 103(a). See also the remaining text of Recommendation 103 and 104. 
trade between a limited number of contracting parties with identical internal regulation."215

\subsection{A 'Narrowly Defined' Exception 216}

Considering that the goal of the GATT was equated with trade liberalization which, in the neoliberal thought, required by its nature the removal of government interventions, and mindful of the risk that broadening GATT exceptions might undermine this goal, GATT panels have consistently ruled that exceptions should be narrowly construed. ${ }^{217}$

This narrow approach can be explained by looking at who sat on these ad-hoc panels and whom they answered to. The Understanding on Dispute Settlement specifies that "in order to facilitate the constitution of panels, the DirectorGeneral should maintain an informal indicative list of governmental and nongovernmental persons qualified in the fields of trade relations, economic development, and other matters covered by the General Agreement."218 As a result, panels ended up being composed of individuals with an expertise in trade and economic matters, and with at least some knowledge of the GATT and, because use of governmental panelists was generally preferred, ${ }^{219}$ panels tended to "inevitably consist of government officials in the trade area."220 In other words, panels were "made up of various members of the insider network ... closely associated with the GATT 'community",'221 had the support of the GATT bureaucracy and were, to a certain extent, controlled by it.

In Tuna/Dolphin, the panel observed that "Article xx provides for an exception to obligations under the General Agreement [and that] the long-standing practice of panels has accordingly been to interpret this provision narrowly, in a manner that preserves the basic objectives and principles of the General Agreement." 222 This approach reaffirmed an interpretation that was already

215 Report of the Gatt Panel, US - Tuna I, para. 5.27. See also Report of the GatT Panel, United States -Restrictions on Imports of Tuna, DS29/R (June 16, 1994) [hereinafter USTuna II], para. 5.26.

216 This is how the GatT Secretariat described Article xx in its 1992 Report on Trade and the Environment, 8.

217 See Jackson, 'Greening the GATT'(n 108) 46.

218 Understanding Regarding Notification, Consultation, Dispute Settlement and Surveillance, GATT B.I.S.D. 200 (26th Supp.) para. 13 (1980) (emphasis added).

219 Decision on Dispute Settlement Procedures, GATT B.I.S.D. (31st Supp.) at 9-10 (1984).

220 William J. Davey, 'Dispute Settlement in GATT' (1987) 11(1) Fordham International Law Journal 52, 88-9.

221 Howse, 'The World Trade Organization 20 Years On'(n 189) 15.

222 Report of the GATt Panel, US - Tuna I, at 5.22. For later statements of this same principle, see Panel Report, US—Shrimps, WT/DS58/R (May 15, 1998), paras 7.36 and 7.37; and 
strict by virtue of the very nature of these clauses-after all, they had been framed as exceptions stricto sensu. In fact, the Panel's decision to interpret Article Xx narrowly in this landmark case was consistent not only with prior GATT decisions ${ }^{223}$ and with the legislative history of the Agreement, but also with the pronouncements of other international courts, all following the Latin maxim exceptio est strictissimae applicationis. ${ }^{224}$ In its dissenting opinion in the North Sea case in relation to Article 6 of the 1958 Continental Shelf Convention, for instance, Judge Tanaka suggested that the "special circumstances" clause, because of its exceptional nature, should have been subject to a strict interpretation. ${ }^{225}$ Likewise, in Qatarv. Bahrain, the International Court of Justice observed that "the method of straight baselines, which is an exception to the normal rules for the determination of baselines ... must be applied restrictively."226 Similar pronouncements have been made by arbitral tribunals as well as by the European Court of Justice (ECJ). ${ }^{227}$ The latter, in particular

Appellate Body Report, United States-Measure Affecting Imports of Woven Wool Shirts and Blouses from India, WT/DS33/AB/R (April 25, 1997) [hereinafter US-Shirts and Blouses], 16 ("Articles XX and XI:1(2)(c)(i) are limited exceptions from obligations under certain other provisions of the GATT 1994, not positive rules establishing obligations in themselves").

223 See Report of the GATT Panel, United States—Section 337 of the Tariff Act of 1930, B.I.S.D. 36S/345, 385 (Nov. 7, 1989) [hereinafter US -Section 337], para. 5.9. ("Article xx(d) thus provides for a limited and conditional exception from obligations under other provisions"). See Hurlock, 'Note' (n 88) 2127.

224 The authoritative source governing treaties' interpretation, the Vienna Convention on the Law of Treaties (VCLT), does not contain any explicit rules regarding the interpretation of exceptions. The principle that exceptions should be interpreted restrictively has been drawn from the domestic practice of interpreting exceptions in statutes, as well as from the Latin maxim exceptio est strictissimae applicationis which is part of general international law and is consistently referred to by international tribunals. Vienna Convention on the Law of Treaties, May 23, 1969, 1155 U.N.T.S. 331 [hereinafter VCLT]. See Jorge E. Viñuales, 'Seven Ways of Escaping a Rule: Of Exceptions and Their Avatars in International Law', in Lorand Bartels and Federica Paddeu (eds.), Exceptions and Defences in International Law (Oxford University Press, 2020).

225 North Sea Continental Shelf (Ger. v. Den.), 1969 I.C.J. 3 (Feb. 1969) (dissenting opinion of Judge Tanaka, at 186).

226 Maritime Delimitation and Territorial Questions Between Qatar and Bahrain (Qatar v. Bahr.) Merits 2001 I.C.J. 40 (Mar. 2001).

227 NAFta Arbitral Panel Established Pursuant to Chapter Twenty: In the Matter of CrossBorder Trucking Services (Secretariat File no. USA-MEX-98-2008-01) [in this case, however, the reference to the principle exceptio est strictissimae applicationis was made with respect to a reservation, and not an exception]. See Asif H. Qureshi, Interpreting WTO Agreements. Problems and Perspectives (Cambridge University Press, 2006), p. 105. Case C-169/oo, Commission of the European Communities v. Republic of Finland, 2002 E.C.R. I-02433. 
has made clear, in a consistent line of case law, that Article 36 must be strictly interpreted. ${ }^{228}$

The individual requirements of paragraphs (b) and (g) have equally been narrowly construed by the panels, who justified the restrictive interpretation of paragraph (b) by relying on its drafting history. The delegates had all agreed that the stipulation "to protect animal or plant life or health" could be misused for indirect protection, ${ }^{229}$ and it is clear from the record of the discussions that the "Commission [was] against any possibility of this provision being used as a measure of protection in disguise."230

Just like it happened for the chapeau, the restrictive and narrow interpretation given to Article $\mathrm{xx}(\mathrm{b})$ and $(\mathrm{g})$ as soon as the first disputes arose, did not reflect the original intent of the Drafting Commission and were not motivated by fear of protectionism but rather by the hostility towards all forms of government intervention which might have affected international trade. Once again, the importance of the distinction between legitimate domestic regulation and regulation with protectionist motives disappeared and the only relevant standard to evaluate such measures was the extent of their impact on trade flows. As a result, the word 'necessary' was initially interpreted as the 'least restrictive alternative':231 in the words of John Jackson, "if there are two or more alternatives that a government could use to protect human life or health, it is not 'necessary' to choose the one that places more restrictions on trade, when an alternative that is equally efficient in protecting human life or health exists."232

228 See e.g., Case C-229/83, Leclerq, 1985, E.C.R. 1, 35; Case C-95/81, Commission v. Italy, 1982, E.C.R. 2,187, 2,204; Case C-113/8o, Commission v. Ireland, 1981, E.C.R. 1,625,1,638; Case C-13/ 68, Salgoil, 1968, E.C.R. 453, 463; Case C-7/68, Commission v. Italy, 1968, E.C.R. 423, 431.

$229 \mathrm{E} / \mathrm{PC} / \mathrm{T} / \mathrm{C} . \mathrm{II} / 3^{2}$ and $\mathrm{E} / \mathrm{PC} / \mathrm{T} / \mathrm{C} . \mathrm{II} / 5 \mathrm{O}$.

230 GATT, Analytical Index: Notes on the drafting, interpretation and application of the Articles of the General Agreement, (3rd edition, 1970), 116. E/PC/T/A/PV/30.

231 Throughout the years, the interpretation of the 'necessity test' under Article $\operatorname{xx}(\mathrm{b})$ has become less stringent, see later Chapter 4.

232 Jackson, 'World Trade Rules and Environmental Policies' (n 12) 1240. Report of the GATT Panel, Thailand - Restrictions on Importation of and Internal Taxes on Cigarettes, DS1o/ R-37S/91 (Nov. 7, 199o) [hereinafter Thailand-Cigarettes], para. 75 ("The panel concluded that the import restrictions imposed by Thailand could be considered 'necessary' ... only if there were no alternative measure consistent with the General Agreement, or less inconsistent with it, which Thailand could reasonably be expected to employ to achieve its health policy objectives"). The panel refers to the report in US - Section 337, which referred "to $\mathrm{xx}(\mathrm{d})$, but they are considered to have the same objective: to allow contracting parties to impose trade restrictive measures inconsistent with the General Agreement to pursue overriding public policy goals to the extent that such inconsistencies are unavoidable." See Report of the GATT Panel, US - Section 337, para. 5.26. For a later decision, see Panel Report, US —Gasoline, para. 6.24. 
The underlying idea, stressed by several panels, was that "this paragraph of Article $\mathrm{xx}$ was intended to allow contracting parties to impose trade restrictive measures inconsistent with the General Agreement to pursue overriding public policy goals to the extent that such inconsistencies were unavoidable." ${ }^{233}$ The same interpretation was given to the exception clause contained in Article 36 of the EEC Treaty. The ECJ in the Danish Bottles case clarified that "if a memberState has a choice between various measures to achieve the same objective, it should choose the means which least restrict the free movement of goods."234

Moreover, the panel in the Tuna/Dolphin decision repeated the GATT Secretariat's dislike for unilateralism ${ }^{235}$ - a dislike for which, once again, no trace can be found in the discussions and intentions of the GATT founders:

The Panel considered that if the broad interpretation of Article $\mathrm{xx}(\mathrm{b})$ suggested by the United States were accepted, each contracting party could unilaterally determine the life or health protection policies from which other contracting parties could not deviate without jeopardizing their rights under the General Agreement. The General Agreement would then no longer constitute a multilateral framework for trade among all contracting parties but would provide legal security only in respect of trade between a limited number of contracting parties with identical internal regulations. ${ }^{236}$

This approach does not take into account, however, that, from an environmental standpoint, unilateralism can sometimes be good. Although multilateral action is preferable, consensus is often difficult to achieve, and faced with the choice between waiting for multilateral action and doing nothing or

233 Report of the GatT Panel, US - Tuna I, para. 5.27 (emphasis added). See also Report of the GATT Panel, Thailand -Cigarettes, paras 73-4.

234 Case C-302/86, Commission v. Denmark, 1988 E.C.R. 4607. See Philippe Sands, 'Danish Bottles and Mexican Tuna' (1992) 1(1) RECIEL 28, 29.

235 See the 1992 GATT Secretariat's report on Trade and the Environment which, as pointed out by Charnovitz, mentions the word 'unilateral' 25 times in a 35-page document, never in a favorable light. Steve Charnovitz, 'GATT and the Environment. Examining the Issues' (1992) 4(3) International Environmental Affairs 203 (1992). See also a Resolution adopted by the United Nations Conference in Trade and Development (UNCTAD) in 1992 and the Rio Declaration, Principle 12. UnCTAD, A New Partnership for Development: The Cartagena Commitment, February 1992, para. 152; United Nations Conference on Environment and Development, Rio de Janeiro, Brazil, June 3-14, 1992, Rio Declaration on Environment and Development, U.N. Doc. A/Conf.151/26/Rev.1 (Vol. I), Annex I (Aug. 12, 1992) [hereinafter Rio Declaration], Principle 12.

236 Report of the GatT Panel, US — Tuna I, para. 5.27 (emphasis added). 
acting unilaterally, from an environmental perspective, the latter is a much better option. Not only has there been, for more than a hundred years, a fruitful interplay between unilateral environmental actions and the negotiation of multilateral environmental treaties, ${ }^{237}$ but unilateralism is also good for the environment because it allows individual countries to set their own ecological goals and standards. ${ }^{238}$

Finally, the panel clarified that the application of the exception was limited to domestic restrictions and could not be used to justify measures of extraterritorial nature, and reached this conclusion by analyzing the legislative history of the provisions which, according to the panel, indicated that "the concerns of the drafters ... focused on the use of sanitary measures ... within the jurisdiction of the importing country."239 However, as pointed out by Charnovitz, this reading presented by the panel is incomplete, as it does not take into account "either the historical context of the 'life and health' exception in trade treaties, or the laws that might have motivated such an exception."240 The reluctance to accept an extrajurisdictional application of Article $\mathrm{xx}(\mathrm{b})$ was, at least in part, motivated by the fear that environmental trade measures would be used to influence other countries. But, because virtually each and every environmental regulation or standard can influence foreign exporters, this reading of the provisions leaves very little room for environmental policy-making and standard-setting. Even more if one considers that the distinction between a nation's environment and the rest of the world's — as the one made by the panel in Tuna/Dolphin - is unhelpful when dealing with global environmental resources or migratory species: "if no country is permitted to take extrajurisdictional action, then much of our biosphere would be unreachable by environmental trade measures." ${ }^{241}$

The rejection of extrajurisdictionality is not limited to paragraph (b) of Article $\mathrm{xx}$ but extends, for the very same reasons, to paragraph $(\mathrm{g})$ as well. ${ }^{242}$

237 For example, the US ban of 1897 on fur seal imports led to the adoption of the North Pacific Fur Seals Convention of 1911, while the US ban of 1969 on the importation of endangered species spurred the negotiation of the Convention on International Trade in Endangered Species of Wild Fauna and Flora of 1973. See Charnovitz, 'GATT and the Environment' (n 235).

238 Setting their own standards for internal and external commerce had been criticized, in particular by developing and least developed countries, as 'eco-imperialism', 'gunboat environmentalism' or 'green vigilantism.' See e.g. Gijs M. d Vries, 'How to Banish EcoImperialism' (Apr. 30, 1992) Journal of Commerce 8A.

239 Report of the GATt Panel, US - Tuna I, para. 5.26 (emphasis added).

240 Charnovitz, 'GATT and the Environment' (n 235).

241 Ibid.

242 Report of the gatt Panel, US - Tuna I, para. 5·32. 
What is different between the two paragraphs is the strength of the link required between the measure at stake and the policy purpose set out in the provision. Unlike paragraph $(\mathrm{b})$, the letter $(\mathrm{g})$ does not require the measure at stake to be 'necessary' to the conservation of exhaustible natural resources. Rather, it suffices that the measure be 'relating to' the achievement of such an objective. As noted by the panel in Canada-Salmon and Herring, "this suggests that Article $\mathrm{xx}(\mathrm{g})$ does not only cover measures that are necessary or essential for the conservation of exhaustible natural resources but a wider range of measures." ${ }^{243}$ Nevertheless, a significant link between the measure and the policy objective was initially required, and the term 'relating to' has accordingly been interpreted as the measure being 'primarily aimed at' the conservation of exhaustible natural resources. ${ }^{244}$ Although broader than (b), the panel has been very clear in stating that Article $\mathrm{xx}(\mathrm{g})$ should not be interpreted so expansively as to subvert the object of the Agreement, but merely to make sure that countries do have the possibility to adopt measures to protect natural resources. ${ }^{245}$

The result is that Article xx, a provision that on paper could have represented a safe harbor for many important environmental initiatives, turned out to be anything but safe. While Article xx was the result of a 'compromise' reached by the GATT negotiators between multilateralism and domestic interventionism, and was designed precisely to allow countries to pursue domestic policy objectives, as long as they were legitimate and not protectionism in disguise, the advent of neoliberalism swept away this distinction, transforming the clause into a shield against any trade restrictive or distortive measure. In fact, limiting the application of the exception by placing strict requirements on the term 'necessary' and 'relating to' - in addition to the requirements of the chapeau-have significantly diminished the ability of the provision to reconcile environmental and economic goals. ${ }^{246}$ What is more, because these increasingly stringent tests have been established by panels on an ad hoc basis, they have created an environment of unpredictability, where national

243 Report of the GatT Panel, Canada-Measures Affecting Exports of Unprocessed Herring and Salmon, L/6268-35S/98 (Mar. 22, 1988) [hereinafter Canada-Herring and Salmon], para. 4.6.

244 Ibid.

245 Panel Report, US - Gasoline, paras 6.38-6.41. The Appellate Body, instead, also stated that "Nor may Article III:4 be given so broad a reach as effectively to emasculate Article $\mathrm{xx}(\mathrm{g})$ and the policies and interests it embodies." Appellate Body Report, US_Gasoline, wT/ DS2/AB/R (Apr. 29, 1996), 18.

246 Housman and Zaelke, 'Trade, Environment, and Sustainable Development' (n 12) 535 . 
authorities may not know whether, at any given time, their environmental policies conform with the GATT or not. ${ }^{247}$

\subsection{Who Bears the Risk of Non-Persuasion?}

The United States had not demonstrated to the Panel—as required of the party invoking an Article Xx exception - that it had exhausted all options reasonably available to it to pursue its dolphin protection objectives through measures consistent with the General Agreement. ${ }^{248}$

Report of the Panel, US -Tuna, 1991

In ruling against the United States, the Tuna/Dolphin panel found that the respondent had not successfully discharged its burden of proof under Article xx. With these words, the panel emphasized a rule that had been applied consistently by international courts and tribunals with respect to the allocation of the burden of proof: "the burden of proof rests upon the party, whether complaining or defending, who asserts the affirmative of a particular claim or defense."249

In the allocation of the burden of proof, the general rule is the rule actori incumbit probatio, according to which "the party who asserts a fact ... is responsible for providing proof thereof." 250 Accordingly, the party claiming the breach of a GATT substantive provision bears the burden of proving that such breach took place. ${ }^{251}$ On the other hand, the respondent who invokes an exception to the general rule carries the burden of demonstrating the compliance with

247 Charnovitz, 'GATT and the Environment' (n 235).

248 Report of the Gatt Panel, US - Tuna I, para. 5.28.

249 Appellate Body Report, US - Shirts and Blouses, at 14. See Henrik Horn and Petros C. Mavroidis, 'Burden of Proof in Environmental Disputes in the wTo: Legal Aspects' (2009) Research Institute for Industrial Economics, IFN Working Paper No. 793, 11. See also Report of the GATT Panel, Canada-Administration of the Foreign Investment Review Act, BISD 30S/140 (Feb. 7, 1984) [hereinafter Canada_FIRA], para. 5.20; ("Since Article $\mathrm{xx}(\mathrm{d})$ is an exception to the General Agreement it is up to Canada, as the party invoking the exception, to demonstrate that the purchase undertakings are necessary to secure compliance with the Foreign Investment Review Act."); and Report of the GATT Panel, US-Section 337, para. 5.27. ("it is up to the contracting party seeking to justify measures under Article $\mathrm{xx}(\mathrm{d})$ to demonstrate that those measures are 'necessary' within the meaning of that provision").

$25^{\circ}$ Mojtaba Kazazi, Burden of Proof and Related Issues: A Study of Evidence Before International Tribunals (Martinus Nijhoff Publishers, 1996), p. 117.

251 Panel Report,Japan - Taxes on Alcoholic Beverages, wT/DS8/R (July 11, 1996) [Addressing the claim under Article II:2, first and second sentence, the panel found that "complainants have the burden of proof to show ... that products are like and ... that foreign products are taxed in excess of domestic ones" with reference to the former, and that "the products concerned are directly competitive or substitutable and that foreign products 
the conditions reflected in the exception (quicumque exceptio invocat eiudem probare debet). ${ }^{252}$

It should be clarified that the term 'burden of proof' is here used to refer to the 'burden of persuasion'. The burden of proof, broadly speaking, can be broken down in different duties or burdens: the 'burden of raising', which refers to the duty to raise a specific claim, the 'burden of production', meaning the duty to produce evidence, and the 'burden of persuasion', which is the burden of proving or disproving a claim and ultimately convince the trier. While the burden of production rests on both parties, as they share the duty to cooperate in the fact-finding process, the burden of persuasion follows the two rules mentioned above. ${ }^{253}$

The allocation of the burden of proof is particularly important and controversial in trade disputes for a number of reasons. ${ }^{254}$ First, the content of many WTO obligations is not entirely clear, and the parties may not know what degree of proof is required for the burden of proof to be successfully discharged (and the same applies to free trade agreements, which often borrow the language of their multilateral counterparts). Second, if defining the allocation of the burden of proof and, in particular, of persuasion, does not necessarily affect the

are taxed in such a way so as to afford protection to domestic production." Paras 6.14 and 6.28]. Appellate Body Report, US - Shirts and Blouses, 14-16.

252 The GATT panels have stressed this rule in several cases with specific reference to GATT Article xx and the Appellate Body has later extended this interpretation to other provisions deemed to constitute "affirmative defences," besides Article Xx. See Report of the GATT Panel, Canada—FIRA, para. 5.20. See also Report of the GATT Panel, US —Section 337, para. 5.27 and United States - Measures Affecting Alcoholic and Malt Beverages, BISD 39S/206 (June 19, 1992), paras 5.41 and 5.52. Later, the Appellate Body continued on this track: see Appellate Body Report, Thailand-Customs and Fiscal Measures on Cigarettes from the Philippines, WT/DS371/AB/R (June 17, 2011), para. 176; Appellate Body Report, Korea-Measures Affecting Imports of Fresh, Chilled and Frozen Beef, wT/Ds161/AB/ R (Dec. 11, 200o), para. 157. Appellate Body Report, US -Shirts and Blouses, at 14-16; Appellate Body Report, US -Gasoline, at 22-3. See also Appellate Body Report, United States-Measures Affecting the Cross-Border Supply of Gambling and Betting Services, wT / DS285/AB/R (Apr. 7, 2005), para. 309 [with regard to GATS Article XIV(a)]. Appellate Body Report, United States - Tax Treatment for 'Foreign Sales Corporations'-Recourse to Article 21.5 of the DSU by the European Communities, WT/DS108/sB/RW (Jan. 14, 2002), para. 133 [with regard to footnote 59 of the ASCM].

253 See e.g. Joost Pauwelyn, 'Defenses and the Burden of Proof in International Law', in Bartles and Paddeu (eds.), Exceptions and Defences in International Law (n 224).

254 The subject of the burden of proof in wTo disputes has been taken up and addressed in a comprehensive manner in Michelle T. Grando, Evidence, Proof, and Fact-Finding in WTO Dispute Settlement (Oxford University Press, 20o9). See also Joost Pauwelyn, 'Evidence, proof and Persuasion in WTo Dispute Settlement. Who Bears the Burden?' (1998) 1Journal of International Economic Law 227 and, more generally, Kazazi, Burden of Proof (n 250). 
outcome of a dispute whenever there are strong grounds to rule in favor of one party or the other, the allocation of the burden of proof becomes a crucial question when the evidence is not sufficient or the arguments are in equipoise.

In those cases, the panel will have to find against the party bearing the burden of proof. Because exception clauses represent the only 'window' that countries can use to introduce environmental values, the burden will constantly fall on the party defending the adoption of trade-restrictive environmental measures and the actual chances of successfully justifying them under Article xx become quite scarce. And as a matter of fact, in several GATT environmental cases (although this issue is of course not limited to the use of Article Xx for environmental purposes), the inability of the respondent to successfully discharge its burden of persuasion contributed to the ultimate outcome of the decision. In one of the first cases brought by Canada against the United States, for instance, it was precisely because "the United States representative had provided no evidence that consumption of tuna and tuna products had been restricted in the United States," which constituted one of the requirements of GATT Article Xx(g) - that the measure at stake be made effective in conjunction with restrictions on domestic production or consumption - that the US prohibition of Canadian tuna could not be justified under the exception clause. ${ }^{255}$

If we combine this procedural requirement with the narrow interpretation reserved to exceptions, the respondent's chances to successfully justify an environmental measure under Article xx become quite scarce. And even scarcer if one pauses to look at the individuals who sat on these panels and what their mandate was.

\subsection{Judges with Limited Mandate and Expertise}

When, among the protests and uprising following the Tuna/Dolphin decision, environmentalists decried the obscure international trade tribunal with no environmental sensitivity or expertise that was challenging and overriding environmental laws and regulations, they were not too far from the truth.

Under the GATT, when the parties were unable to settle their differences through consultation or mediation, the resolution of disputes was governed by Article XXIII of the Agreement which, rather than establishing any formal procedures for handling such disputes, simply offered a broad outline of the overall process. Since the early 195os, the use of panels had become the standard

255 Report of the GatT Panel, United States-Prohibition of Imports of Tuna and Tuna Products from Canada, L/5198—29S/91 (Feb. 22, 1982) [hereinafter US -Canadian Tuna], paras 4.11 and 4.12. See also Report of the GATT Panel, US - Tuna I, para. 5.28. 
practice:256 "following the inability of two contracting parties to resolve a dispute through consultations and negotiations, the aggrieved party may request the appointment of a panel to adjudicate the dispute."257 The panel, generally composed of three or five members, was appointed by the Director General, received the written submissions of the parties and, following the parties' comments to an interim draft, submitted its final report to the GATT council.

Trade disputes that presented an environmental component would require the members of the panel to weigh the merits of competing trade and environmental claims. Such weighing would involve understanding the scientific evidence presented, as well as the societal dimension that tends to characterize environmental disputes. ${ }^{258}$ However, such a balancing act of environmental, economic, and other concerns encountered several obstacles along the way.

First, when interpreting and applying GATT rules, the members of the panels established under the GATT lacked the mandate to rely on environmental provisions or principles. To the contrary, the measures at stake in each dispute could be examined solely "in the light of the relevant GATT provisions," 259 as clarified in the Understanding on Dispute Settlement adopted at the end of the Tokyo Round, intended to summarize the dispute settlement procedures that had traditionally been used in GATT and which would continue to be used in the future. ${ }^{260}$ Accordingly, in Canada-Salmon and Herring, the panel refused to take into account certain provisions of the United Nations Convention on

256 During the first few years of the GATT, up until 1952, disputes were generally considered by working parties, consisting of the contending nations and several other GATT members.

257 Davey, 'Dispute Settlement in GATT' (n 220) 58.

258 US Congress, Office of Technology Assessment, Trade and Environment: Conflicts and Opportunities (US Government Printing Office, May 1992), 77. In 1993, Jeffrey Dunoff argued that "trade-environment conflicts should be heard before an institution that recognizes the interdependent nature of global economic and environmental issues and that has a mandate to advance both economic development and environmental protection. This body should have ready access to the scientific and technical expertise that would enable it to resolve trade-environment disputes knowledgeably." Jeffrey L. Dunoff, 'Institutional Misfits: The GATT, the ICJ \& Trade-Environment Disputes' (1993) 15 Michigan Journal of International Law 1043, 1046.

259 GatT, Understanding Regarding Notification, Consultation, Dispute Settlement and Surveillance, 207-8. See Report of the GATT Panel, US —Canadian Tuna, para. 4.1; Report of the GATT Panel, United States - Imports of Sugar from Nicaragua, L/5607-31S/67 (Mar. 13, 1984) [hereinafter US —Sugar Quota], para. 4.1; Report of the Panel, United StatesTrade Measures Affecting Nicaragua, L/6053 (Oct. 13, 1986), para. 5.15; Report of the Panel, Canada-Herring and Salmon, para. 5.3; Report of the Panel, Thailand-Cigarettes, para. 2.

Davey, 'Dispute Settlement in GATT' (n 220) 58. 
the Law of the Sea (UNCLOS) and certain fisheries agreements in its examination of Canada's prohibition of export of unprocessed herring and pink and sockeye salmon. ${ }^{261}$ In an earlier decision-US—Trade Measures Affecting Nicaragua - the panel, while agreeing with Nicaragua that the GATT could not operate in a vacuum and that GATT provisions had to be interpreted within the context of the general principles of international law, nevertheless considered it to be outside its mandate to address certain non-trade questions because its task was to examine the case before it "in the light of the relevant GATT provisions," although they might be inadequate and incomplete for the purpose. ${ }^{262}$ Because trade agreements, as mentioned above, did not feature any environmental rules, it follows that, whenever a dispute arose, it was decided almost solely based on standards developed and applied by trade experts, on the basis of free trade principles.

Moreover, as demonstrated earlier by describing the background of these judges, they generally lacked the required environmental expertise. There was, at least in theory, a way to compensate for this lack of expertise: the Understanding on Dispute Settlement explains that "each panel should have the right to seek information and technical advice from any individual or body which it deems appropriate."263 This provision, although it does recognize the panel's right to consult external experts, does not contain any obligation to do so: it is ultimately a prerogative of the panelists to decide whether such external input is necessary for the resolution of the dispute at hand, and in none of the environmental disputes raised before the establishment of the wто in 1995, did the panel deem fit to make use of this possibility. ${ }^{264}$

261 Report of the GATT Panel, Canada-Herring and Salmon, para. 3.

262 Report of the GATT Panel, US —Sugar Quota, para. 5.15.

263 GatT, Understanding Regarding Notification, Consultation, Dispute Settlement and Surveillance (n 259) para. 15.

264 The only exception being the Thailand - Cigarettes dispute which, however, dealt with a health rather than an environmental measure. In this case, the Panel requested the expert opinion of the World Health Organization (wHo) and relied on its factual determinations throughout the whole report. Here it had been inserted in the Memorandum of Understanding of the Parties that if one of them did ask to consult a competent international organization, the Panel should have proceeded accordingly, and Thailand did ask. Report of the GATT Panel, Thailand - Cigarettes, at 73: "In agreement with the parties to the dispute and the expert from the wHO, the Panel accepted that smoking constituted a serious risk to human health and that consequently measures designed to reduce the consumption of cigarettes fell within the scope of Article $\mathrm{xx}(\mathrm{b})$." See Joost Pauwelyn, "The Use of Experts in WTO Dispute Settlement' (2002) 51(2) International \& Comparative Law Quarterly 325. 
One last limit of the system lay in it being a 'black box', where only the parties to the GATT could participate in the proceedings-those involved in the dispute and any other contracting party having a substantial interest in the matter after having notified the Council. ${ }^{265}$ Nongovernmental organizations or other private entities, on the other hand, were not allowed to participate in the GATT dispute resolution process as amici curiae, witnesses, or even observers. ${ }^{266}$ However, given the significant involvement of scientific data in environmental disputes, allowing access to environmental NGO s would have increased the information available to the panel, allowing its members to adopt better informed - and more balanced-decisions, and it would have enhanced the legitimacy of the final judgment. ${ }^{267}$ In neglecting the role of these organizations, the GATT seems to not only part from the practice shared by the vast majority of international organizations, which largely draw on the expertise of NGO s in their work, but to even forget the original intentions of the Havana negotiators: the Havana Charter itself, which was supposed to establish the International Trade Organization (ITO), provided that the Organization "may make suitable arrangements for consultation and co-operation with nongovernmental organizations concerned with matters within the scope of this Charter."268

\subsection{Trade Liberalization First}

What this chapter has described are the concurring circumstances that have led to the adoption of a trade-centered approach to the trade/environment nexus: an approach where economic growth through trade liberalization represents the primary goal of trade agreements, and trade rules simply proscribe government actions that could disrupt the free flow of commerce. Environmental protection is mostly seen as a potential obstacle to smooth

265 GATT, Understanding Regarding Notification, Consultation, Dispute Settlement and Surveillance (n 259) para 15, and Annex at iv.

266 See Steve Charnovitz, 'Participation of Nongovernmental Organizations in the World Trade Organization' (1996) 17(1) University of Pennsylvania Journal of International Economic Law 331, 348-356; David Wirth, 'Reexamining Decision-Making Processes in International Environmental Law' (1994) 79 Iowa Law Review 769, 786-7.

267 Charnovitz, 'Participation of Nongovernmental Organizations' (n 266) 351. Without forgetting that it would also increase the legitimacy of the GATT. See Kevin Stairs and Peter Taylor, 'Non-Governmental Organizations and the Legal Protection of the Oceans: A Case Study', in Andrew Hurrell and Benedict Kingsbury (eds.), The International Politics of the Environment (1992), p. 134; Pauwelyn, 'The Use of Experts' (n 264) 330.

268 Havana Charter for an International Trade Organization, 1948, U.N. Doc. E/CONF.2/78, Art. 87(2). 
trade flows and, as a result, enters trade agreements through narrow exceptions, interpreted and applied by panels who lack any environmental expertise and whose rules and procedures are criticized for being biased towards trade values. Following this approach, environmental standards are addressed only to the extent that they are 'too high' while no mechanism exists to address standards that would qualify as 'too low'. Where the legitimacy of environmental regulations depends solely on what is produced, rather than how it is produced, the environmental footprint of processes and production methods is not taken into account in the substantive provisions of the agreements.

As time went by, environmental and trade values came to clash against each other increasingly frequently, as evidenced by the GATT dispute settlement system being used "more frequently for the settlement of 'environmental disputes' between states than any other international dispute settlement mechanism,"269 although it was never intended to play this role. Soon, the two communities could not live in isolation any longer, and initiating a constructive dialogue between them became imperative. It was time to address the elephant in the room: countries were increasingly adopting trade measures to protect the environment and more and more environmental agreements started featuring provisions that legitimized them. It was time to find ways for free trade and environmental protection to peacefully coexist, rather than being an 'irreconcilable conflict.'

269 Petersmann, 'International Trade Law and International Environmental Law' (n 12) 53. 